\title{
İşgörenlerde Algılanan Örgütsel Destek Algısı İle Örgütsel Bağlılık İlişkisinde İşs Tatmininin Aracı Rolü \\ (In Employees Intermediary Role of Job Satisfaction in Relationship between Organizational Commitment and Perceived Organizational Support)
}

\author{
Ahmet DİKEN iD a Nezahat KOÇYİ̆İT iD b Ebru Özer TOPALOĞLU iD c Aylin YILMAZ iD d \\ a Necmettin Erbakan Üniversitesi, İşletme Bölümü, Konya, Türkiye. adiken@erbakan.edu.tr \\ b Necmettin Erbakan Üniversitesi, Yönetim Bilişim Sistemleri Bölümü, Konya, Türkiye. nkocyigit@erbakan.edu.tr \\ c Necmettin Erbakan Üniversitesi, Muhasebe ve Finans Yönetimi Bölümü, Konya, Türkiye. eozer@erbakan.edu.tr \\ d Karamanoğlu Mehmetbey Üniversitesi, Turizm ve Otel İşletmeciliği Bölümü, Karaman, Türkiye. aylinyilmaz@kmu.edu.tr
}

\begin{tabular}{ll}
\hline MAKALE BILGGisi & ÖZET \\
\hline Anahtar Kelimeler: & Amaç - Algılanan örgütsel destek, işletmelerde işveren ve iş gören arasındaki ilişkiyi ortaya \\
koyması bakımından önem taşıyan bir kavramdır. Örgütsel destek algısı yüksek olan işrenlerin \\
İş Tatmini & daha yüksek örgütsel bağlllı davranışı sergiledikleri de yadsınamaz bir gerçektir. Bu nedenle \\
Öğretmenler & araştırmada çalışanlarda örgütsel destek algısını oluşturan faktörlerin neler olduğunu, bu algının \\
Örgütsel Bağlılık & örgütsel bağlllık ile olan ilişkisini ve bu ilişkide iş tatmininin aracı rolünü ortaya koymak \\
Örgütsel Destek & amaçlanmıştır.
\end{tabular}

Gönderilme Tarihi 18 Ağustos 2019

Revizyon Tarihi 10 Kasım 2019

Kabul Tarihi 18 Kasım 2019

Makale Kategorisi:

Araştırma Makalesi

Yöntem - Konu ile ilgili işletmelerde çok sayıda çalışmanın varlığı, fakat eğitim gibi önemli bir sektör, öğretmenlik gibi önemli bir meslek alanında yapılan çalışmaların sayısının azlığı bu araştırmanın öneminin belirlenmesinde etkili olmuştur. Araştırmada veri toplama yöntemi olarak nicel araştırma tasarımı ve verilerin toplanmasında anket tekniği kullanılmıştır ve örneklem belirlenirken maliyet ve zaman unsuru da dikkate alınarak basit tesadüfi örnekleme yöntemi seçilmiştir. Araştırmanın örneklemini evrenin içinden erişilebilen ve yüz yüze görüşülen Konya İli genel ve özel liselerinde çalışan 300 öğretmen oluşturmaktadır. Toplanan veriler kapsamında; ölçeklerin geçerlik ve güvenirlik analizleri, Ki-kare analizleri, Anova testleri, normallik testleri, faktör analizleri ve yapısal eşitlik modellemesi yapılmıştır.

Bulgular - Analizler sonucunda iş tatmini ile örgütsel bağlılık algısı arasında karşılıklı ve olumlu bir ilişki, iş tatmini ile örgütsel destek algısı arasında karşılıklı ve olumlu bir ilişki olduğu bulgularına ulaşılmıştır. Yapısal eşitlik modeli sonuçlarına göre uyum indekslerinin iyi uyum düzeyine yakın olduğu görülmüştür ve model-veri uyumuna sahip olduğu sonucuna ulaşılmıştır. Hipotezler desteklenmiştir (H1, H2 ve H3).

Tartışma - Çalışmada öğretmenlerin en fazla iş tatmini sağladıkları ve örgütsel destek algısının yüksek olduğu alanlar; mesleğin öğrencileri yönlendirmede fırsat ve başkaları için bir şeyler yapabilme hissi vermesi olarak tespit edilmiştir. Terfi imkânları ise iş tatminini azaltan etkenler arasında bulunmuştur.

\begin{tabular}{|c|c|}
\hline ARTICLE INFO & ABSTRACT \\
\hline $\begin{array}{l}\text { Keywords: } \\
\text { Job Satisfaction } \\
\text { Teachers } \\
\text { Organizational Commitment } \\
\text { Organizational Support }\end{array}$ & $\begin{array}{l}\text { Purpose - Perceived organizational support is a concept which is important in terms of revealing } \\
\text { the relationship between employer and employee in enterprises. It is an undeniable fact that those } \\
\text { who have high perception of organizational support exhibit higher organizational commitment } \\
\text { behavior. Therefore, in this research is aimed to determine the factors that constitute the perception } \\
\text { of organizational support in employees, the relationship between this perception and organizational } \\
\text { commitment and mediating role of job satisfaction in this relationship. }\end{array}$ \\
\hline $\begin{array}{l}\text { Received } 18 \text { August } 2019 \\
\text { Revised } 10 \text { November } 2019 \\
\text { Accepted } 18 \text { November } 2019\end{array}$ & $\begin{array}{l}\text { Design/methodology/approach - The existence of a large number of researches in enterprises, but } \\
\text { an important sector such as education, the lack of number of studies related to the subject in an } \\
\text { important profession such as teaching was effective in determining the universe of this study. } \\
\text { Survey method was applied as a method. Simple random sampling method was chosen considering } \\
\text { cost and time. The sample of the research consisted of } 300 \text { teachers working in public and private }\end{array}$ \\
\hline $\begin{array}{l}\text { Article Classification: } \\
\text { Research Article }\end{array}$ & $\begin{array}{l}\text { high schools in Konya. Within the context of collected data; was made validity and reliability } \\
\text { analysis of the scales, Chi-square analysis, Anova tests, normality tests, factor analysis and structural } \\
\text { equation modeling. Hypotheses are supported. }\end{array}$ \\
\hline
\end{tabular}

\section{Önerilen Atıf/ Suggested Citation}

Diken, A., Koçyiğit, N., Topaloğlu, E.Ö., Yılmaz, A. (2019) İşgörenlerde Algılanan Örgütsel Destek Algısı İle Örgütsel Bağlllık İlişkisinde İş Tatmininin Aracı Rolü, İşletme Araştırmaları Dergisi, 11 (4), 2698-2716. 


\begin{abstract}
Findings: As a result of the analyzes it was found that there was a mutual and positive effect between job satisfaction and organizational commitment perception, and there was a mutual and positive effect between job satisfaction and organizational support perception. According to the results of the structural equation model, the fit indexes were found to be close to the good fit level and It was concluded that the model-data compatibility.

Discussion - In this study; areas of teachers' most job satisfaction and the perception of high organizational support; the profession has been the opportunity to guide students and give them a feeling of doing something for others. Promotion opportunities were found to be among the factors reducing job satisfaction.
\end{abstract}

\title{
Gíriş
}

İnsan hayatının çoğunluğunu iş yerinde geçirmektedir. Haz duyduğu işleri yapmak ve olumlu duygusal çıktılar edinmek insanı mutlu etmektedir ve mutlu insan aynı zamanda verimli ve etkili çalışan demektir. Gerek kamu sektöründeki gerekse özel sektördeki örgütlerde insan unsurunu en iyi şekilde değerlendirmek gerekmektedir.

Eğitim ve sağlik devletin kontrolü altında olan ve iyileştirilmesi ve geliştirilmesi en önemli hizmetlerdendir. Özellikle eğitim sistemi, bireylerinin niteliğini ve yetkinliğini artırmak isteyen toplumlar için her kişinin başarılı bir okulda, en iyi öğretmenler tarafından yetiştirilmesi yönünde çaba harcandığı bir alandır. Bu çabada en büyük görev öğretmenlere düşmektedir. Öğretmenlerin görevlerini en iyi şekilde yapabilmesinde ise okul içerisindeki çalışma ortamı, yönetici desteği ve kuruma olan bağlllıkları en önemli faktörler arasında gelmektedir.

Öğretmenlik mesleğinde kendini ön plana çıaran kavramlardan biri algılanan örgütsel destektir. Çünkü eğitim ve öğretimde yaşanan sorunların başında; kalabalık sınıfların, okul-aile ve öğrenci-öğretmen çatışmalarının, yetersiz fiziki koşulların, politik ve sosyal güçlerin eğitim kurumlarına olan baskısının, toplumsal eleştiri ve baskıların, terfi etmede yaşanan sorunların geldiği düşünüldüğünde burada öğretmenlere ve dahası eğitim sektörüne verilecek desteğin önemi artmaktadır. Bu nedenle öğretmenlerin örgütsel destek algısını, bu algının öncüllerini ve sonuçlarını ortaya çıkarmak, daha yüksek edimle çalışmalarını sağlayabilmek açısından önem taşımaktadır.

Okullar; ortaöğretimden yükseköğretime, meslek hayatına ve iş yaşamına, öğrencileri hazırlamanın yanı sıra, kimlik arayışı içinde olan ve ergenlik gibi zor bir dönemi geçiren bireylerin destek alabileceği ortamlar sağlamaktadır. Bu desteğin en önemli aktörü de yine kuşkusuz öğretmenlerdir. Dolayısıyla öğretmenlerin öğrencilere vereceği desteğin tabanında kendilerinin çalıştıkları ortamda algıladıkları destek ve bu desteğin sonucunda oluşacak örgütsel aidiyetleri ve iş tatminleri büyük önem arz etmektedir. Öğretmenlere yöneticiler, bakanlıklar ve sivil toplum kuruluşları gibi kurumlardan verilecek destekler arasında; bilgi, rehberlik, çalışma ve performansları hakkında geri bildirim, terfi desteği ve maddi destekler gibi sosyal ve psikolojik destekler gelmektedir.

Araştırmalarda algılanan örgütsel destek sonucu, örgütsel bağlılı̆̆ın, iş tatmininin, işe katılmanın, işe devamlılığın arttığı, stresin ve devamsızlığın azaldığı yönünde bulgulara ulaşılmıştır. Ülkemizde öğretmenlerin ve eğitim alanındaki yöneticilerin görevlerinden ne derece memnun oldukları, görev yaptıkları kurumla ne derece özdeşleştikleri esasen onların örgütsel bağlılık ve iş tatmin düzeylerini de göstermektedir. Bu nedenle mesleğin gelişiminde öğretmenlerin ne tür destekler beklediklerinin, algılanan bu desteğin işe olan bağlılıklarına olan etkisinin ve sağlanan iş tatmininin bu etkideki rolünün ve eğitim kalitesini artıran faktörlerin belirlenmesi yerinde olacaktır.

\section{KAVRAMSAL ÇERÇEVE}

\subsection{Algılanan Örgütsel Destek}

Algılanan örgütsel destek kavramı, 1986'dan bu yana örgütsel davranış alanının konusu haline gelmiş, çalışan motivasyonu ve performansının önemli bir belirleyicisi olduğu ortaya konulmuştur. Algı ve örgütsel destek kavramlarının sonucu olarak ortaya çıkan algılanan örgütsel destek; iş görenin çalıştığı kurumun bireysel kariyer ve kişisel gelişimine yönelik gönüllü katkı sağladığına ve kendisinin sahiplenildiğine olan inancıdır (Erkoç, 2015: 1). Başka bir ifade ile çalışanların kuruma yaptıkları katkılarının ne derece karşılık alabildiğine ve mutluluklarının kurum tarafından ne kadar önemsendiğine dair olumlu ya da olumsuz yargılarıdır (Üren ve Çorbacıoğlu, 2012: 32). Literatürde yer alan başka bir tanıma göre algılanan örgütsel destek; bir çalışanın 
içerisinde bulunduğu örgütün katkılarına verdiği değerin boyutları hakkında kendisinde oluşan inancıdır (Roover, 2015: 10).

Eisenberger ve arkadaşları (1986) ise konu ile ilgili örgütsel destek teorisini ortaya koyarak, örgüt ile çalışan arasındaki iş koşullarından performans ve ödüllendirme sistemlerine kadar her türlü ilişkinin kaliteli olmasına, çalışanların refah düzeylerinin arttığı mutlu bir ortamda çalıştıklarını hissetmelerine kadar dikkatleri çekmiştir. Burada karşılıklılık normuna göre; çalışanla örgüt arasında yazılı olmayan fakat çalışanların göstermiş oldukları performansın ve olumlu faaliyetlerin örgütte ödüllendirme, terfi ve rahat bir çalışma ortamı gibi tatmin edici geri dönüşler sağlayacağı yönünde kanaatlerine dayanan sözel bir anlaşma olduğu düşünülmektedir. Bu karşılıklılık ilişkisinde tarafların yapacakları ihmaller örgütsel süreçleri zedeleyebileceği gibi güveni de sekteye uğratabilmektedir. Çalışan örgüt tarafından çeşitli yönlerden desteklenirse (menfaatlerinin ve refahının önemsenmesi, emeklerine ve katkılarına değer verilmesi, üstün performansının ödüllendirilmesi, adil bir maaş gibi) örgütsel hedeflere ulaşılması konusunda daha fazla çaba harcaması gerektiğine olan inancını geliştirdiği ve duygusal bağlılığını artırdığı görülmektedir. (Eisenberger, vd., 1986: 501).

Eisenberger ve arkadaşları (1986)'nın bu yaklaşımından farklı örgütsel destek kavramının gelişiminde iki temel teori daha vardır. Bunlar; sosyal mübadele teorisi ve birey davranışlarının örgüte atfedildiği teoridir. Levinson'un (1965), birey davranışlarının örgüte atfedildiği karşılıklılık teorisine göre çalışanlar örgütü kişileştirmeye meyillidir. Bunun altında bireylerin örgütteki davranışlarının ve rollerinin belirlenmesinde, devamlılığında ve başkaları üzerinde kullanacağı güçte örgüt kültürünün, normlarının ve politikalarının etkili olması ve bireylerin bu davranışları ile ilgili yasal, finansal ve ahlaki sorumluluklar taşıması yatmaktadır.

Sosyal değişim teorisinde ise bir değiş-tokuş, karşılıklı iletişim ve etkileşim ilkesi işlemektedir (İlişen, 2017: 27). Çalışan kendi menfaatine olan faydalar sağlandığına inandığında kendisi de verimli olma, gönüllü davranışlarda bulunma tavrı gösterecektir ki bu durumun güven, çalışan memnuniyeti ve bağlılığı sağlaması durumunda iş veriminin de artacağ

Algılanan örgütsel destek ile ilgili çalışmalar incelendiğinde, örgüt yönetimi tarafından desteklendiğine dair algısı yüksek olan çalışanların, işe geç gelme, işe gelmeme, iş ile ilgilisi olmayan konuşmalar yapmak gibi davranışlardan uzak durduğu tespit edilmektedir. Ayrıca yapılan çalışmalar algılanan örgütsel desteğin örgütsel özdeşleşmeyi olumlu yönde etkileyip, iş gören devir hızını düşürdügü ve işten ayrılma niyeti ile negatif yönlü bir ilişki içerisinde olduğunu ortaya koymaktadır (Oktar, 2015: 26).

Örgüt tarafından destek gördüğüne dair algıya sahip olan çalışanların minnettarlık duygusunu hissederek örgüte bağlanarak karşılık verme ihtimalleri artmaktadır (Kaplan ve Ögüt, 2012: 389). Algılanan destek personele ücret ve diğer yan hakları sağlamanın yanı sıra, aynı zamanda saygı ve statüyü de beraberinde getirmektedir (Biswas ve Bhatnagar, 2013: 29).

Kraimer ve Wayne (2014: 217), işe uyum desteği, kariyer desteği ve finansal destek olmak üzere küresel algılanan örgütsel desteğin çok boyutlu olabileceğini belirtmektedirler. Kararlara katılma olanağı sağlanması ve biçimsel ödüllerden fazlasının verilmesi örgütsel destek algısını güçlendirmekte ve olumlu yönde etkilemektir. Çalışanlara örgüt içerisinde ödül ve unvan gibi önemli gördükleri şeyleri vermenin, stres oluşturabilecek faktörlerin ortadan kaldırılmasının, başarının takdir edilmesinin çalışanların örgütsel destek algılarında etkili olduğu araştırmacılar tarafından ele alınan diğer boyutlardır (Akgündüz ve Çakıcı, 2015: 30). Algılanan örgütsel desteği etkileyen diğer faktörler arasında bireysel faktörler, örgütsel adalet ve yönetici desteği olduğu belirtilmektedir (Erkoç, 2015: 10).

Çok sayıda çalışmada, algılanan örgütsel desteğin ve duygusal bağlılığın güçlü bir şekilde ilişkili oldukları ve benzer öncüllere ve sonuçlara sahip oldukları bulgusuna ulaşılmıştır. Duygusal bağlılıkla iş gören devri, performans ve cironun da ilişkili oldukları vurgulanmaktadır. Bu görüşe uygun olarak, örgütte sosyoduygusal ihtiyaçların karşılanması, yönetici desteği ve fazladan rol performansı gibi çabaların ödüllendirilmesi söz konusudur (Rhoades ve Eisenberger, 2002: 698, Rhoades, vd., 2001: 825).

Önderoğlu (2010) çalışmasında örgütsel adalet algıları ile iş aile çatışması arasındaki ilişkide algılanan örgütsel desteğin aracı rolünü ortaya çıkarmıştır. 
A. Diken- N. Koçyiğit - E. Ö. Topaloğlu - A. Yılmaz 11/4 (2019) 2698-2716

Chiang ve Hsieh (2012) çalışmalarında algılanan örgütsel desteğin ve psikolojik güçlendirmenin örgütsel vatandaşlık davranışını olumlu yönde etki ettiği sonucuna varmışlardır.

Gürbüz (2012) çalışmasında algılanan örgütsel destek ve örgütsel güven ile örgütsel bağlllık boyutları arasındaki ilişkiyi ortaya koyarak, örgütsel destek ve güvenin örgütsel bağlllık üzerine olan etkisini belirlemiştir.

Kaya (2012) araştırmasında örgütsel destek ile kariyer tatmini arasında ilişki bulmuş ve yine örgütsel desteğin, işten ayrılma niyeti ile arasında orta düzeyde bir ilişki bulmuştur. Aynı zamanda örgütsel desteğin ve kariyer tatmininin, işten ayrılma niyetinin bir yordayıcısı olduğu da belirlenmiştir.

Üren ve Çorbacıoğlu (2012) örgütsel desteğin, örgütsel bağlllık ve örgütsel bağlllı̆̆ın boyutlarından; duygusal bağlılık, devam ve normatif bağlılığı üzerindeki etkisini belirlemek amacıyla yaptıkları araştırmalarında örgütsel destek ile örgütsel bağlılık, duygusal bağllılı ve normatif bağlllık arasında anlamlı bir ilişkinin varlığını ortaya koymuşlardır.

Erdem (2014) çalışmasında, psikolojik sermayenin algılanan örgütsel destek ile problem odaklı stresle başa çıkma davranışı arasındaki ilişkide aracı rolünün olduğunu tespit etmiştir.

Erkoç (2015) araştırmasında çalışanların kişisel gelişimine yönelik verilen destekle bağlamsal performans ve görev performansı arasında pozitif bir ilişki bulmuştur.

Oktar (2015) çalışmasında algılanan örgütsel desteğin iş tatmini üzerinde pozitif etkisi olduğunu tespit etmiştir.

Roover (2015) çalışmasında kültürün doğrudan algılanan örgütsel desteği etkilediği, algılanan örgütsel desteğin kültür ve kişisel gelişim arasındaki ilişkiye aracılık ettiği bulgusuna ulaşmıştır.

Sezgin (2015) araştırmasında iç girişimcilik davranışının boyutları ve örgütsel destek ilişkisinde örgütsel güvenin tam aracı rolünü tespit etmiştir.

Ulutaş (2015) çalışmasında çalışanların aldıkları örgütsel desteğin, eğitim, iş garantisi, performans bazlı ücret gibi işle ilgili konularda pozitif yönde etki ettiği sonucuna ulaşmıştır.

Eisenberger, vd. (2001) araştırmalarında örgütsel destek teorisine göre, algılanan örgütsel desteğin duygusal bağlılığı ve performansı karşılıklılık normu ile güçlendirdiği varsayımıyla tutarlı bulgulara ulaşmışlardır.

\section{2. Örgütsel Bağlılık}

Latince bir kökten türemiş olan "bağlllık" sözcügü Türk Dil Kurumu tarafından birine karşı yakınlık, sevgi, saygı duyma ve gösterme, sadakat olarak tanımlanmıştır (TDK, 2014). Bununla birlikte bağlllık kavramı ile ilgili alan yazında çok sayıda farklı tanıma ulaşmak mümkündür. Meyer ve Allen (1997: 11) bağlılık kavramını; örgüte karşı duygusal bir bağlllık olarak ifade ederken, örgütten ayrılmanın getireceği maliyetlerin farkındalığına işaret ederek, örgütte devam etmeyi sağlayan bir ihtiyaç ve zorunluluk olarak tanımlamışlardır.

Bayram ise çalışmasında örgütsel bağlılık kavramını; iş görenin örgütün başarılı olması için örgüte karşı olan ilgisi, sadakati ve tutumu olarak tanımlamaktadır. Bayram'a (2005: 125) göre yöneticinin liderlik vasıfları, yaşı, kıdemi, iş dizaynı gibi değişkenlerin örgütsel bağllık tutumunda önemli rol oynadığı belirtilmektedir (Bayram, 2005: 125).

Meyer ve Allen, örgütsel bağlllı̆̆ın çeşitli tanımlarında "çalışanın kuruluşla ilişkisini karakterize eden ve kurumda devam etme kararını gösterir psikolojik bir durum olduğu" görüşünün ortak olduğunu belirtmektedirler (Meyer ve Allen, 1997: 11)

Örgütsel bağlılıkla ilgili araştırmalar William Whyte tarafından kaleme alınan "Örgüt İnsanı" adlı eser ile birlikte artmıştır. Bu çalışmasında Whyte aşırı bağlılığın tehlikelerini açıklamıştır ve örgüt insanını örgüt için çalışmanın ötesinde örgüte ait biri olarak tanımlamıştır. Whyte'e göre örgütte çalı̧̧anlar grubun üretkenlik kaynağıdırlar ve sahiplik duygusunun bireyin nihai ihtiyacı olduğuna inanılmaktadır (Randall, 1987: 460).

Porter, Steers ve Mowday (1974) yaptıkları çalışmada örgütsel bağlılığı; belirli bir örgütün içinde bir kişinin özdeşleşme ve katılım gücü açısından tanımlamışlardır (Sürücü ve Maşlakçı, 2018: 51). Bu tanımlamaya göre örgütsel bağlılığın üç temel unsuru vardır. Bunlar (Bayram, 2005: 127): 
- Bireyin güçlü bir inanç ile kurumun amaç ve değerlerini benimsemesi,

- Bireyin kurum adına anlamlı bir çaba göstermeye istekli olması,

• Bireyin örgüt üyeliğini sürdürmek için güçlü bir istek duyması.

Yüksel'e (2007) göre örgütsel bağl1lık, psikolojik bağl1lığı da ifade etmektedir ki psikolojik bağlllık; sadakat, örgütsel değerlere inanç, bireyin örgüte katılımı gibi unsurları da içermektedir. Yüksel (2007) ayrıca çalışmasında örgütsel bağlılığı üç aşamalı bir süreç olarak açıklamıştır. Bu aşamalar şöyledir:

- Uyum Aşaması: Bu aşamada birey, elde edeceği fayda ve menfaatler karşılı̆̆ında başkaları tarafından etkilenmeyi kabul etmektedir.

- Kimlik Bulma Aşaması: Bu aşama da ise birey, örgüte ait olmaktan gurur duyma ve tatmin edici ilişki sağlamak amacıyla başkalarının etkisini kabul etmektedir.

- İçselleştirme Aşaması: Bu aşamada ise birey, örgütün değerlerini kendi bireysel değerlerine uygun bulmakta ve örgüt değerlerinin kendisine içsel ödül sağladığını keşfetmektedir.

Balay’a göre örgütsel bağlllığın örgütler için hayati öneme sahip bir kavram haline geldiği görülmüştür. Bu kavram; çalışan moral ve motivasyonu, performans, devamsızlık, iş tatmini, işi bırakma, geri çekilme gibi tutumsal, bilişsel ve duygusal yapılarla ve sorumluluk, özerklik, görev anlayışı, işe katılım gibi iş görenin görevine ve işteki rolüne ilişkin özelliklerle ilişkilidir. Ayrıca kavram cinsiyet, yaş, hizmet süresi, eğitim gibi iş gören kişilik özellikleri ve örgüte bağlılık ile de yakından ilişkilidir (Balay, 2000: 1).

Örgütler için kaynakların etkin kullanımı günümüz rekabet edebilirlik şartlarında önemli olduğundan örgütler, genellikle yüksek iş gücü devir oranından kaynaklı fazla maliyeti azaltmak ve devamlılığı sağlamak için çalışanların örgüte olan bağlılıklarını artırmaya çalışmaktadırlar. Örgütsel bağlılığı yüksek çalışanların daha çok çalışarak örgütsel amaçların başarılmasında daha fazla fedakârlık yapacakları ve görev üstü davranışlar göstereceklerine inanılmaktadır. Araştırmalar, örgütsel bağlılığın maliyeti azaltmasındaki etkenin yüksek iş gücü devir oranından kaynaklandığını göstermektedir.

Araştırmalar, örgütsel bağlllı̆̆ın yüksek iş gücü devir oranından kaynaklanan maliyeti azalttığını göstermektedir (Meyer ve Allen, 2004: 2).

Doğan'a göre örgütsel bağlılığı daha iyi anlamak, sadece çalışanları daha mutlu ve daha verimli yapma potansiyeline sahip olmakla kalmaz; aynı zamanda, bağlılık biçimlerini araştırırken elde edilen bilgiler başka alanlara da yayılabilir. Bir de bireylerin ait oldukları örgütlerle olan bağlarının düzeyi, genel anlamda toplumu da etkiler (Doğan, 2013: 70). Mathieu ve Zajac çalışmalarında örgütsel bağlllığı ortaya çıkaran faktörleri şu şekilde açıklamışlardır (Mathieu ve Zajac, 1990: 174):

- Yaş, eğitim, cinsiyet, ücret, yetenek, statü gibi kişisel özellikler,

- Rol çatışması, rol belirsizliği, aşırı rol

• İşin özellikleri (İşin gerektirdiği beceriler, özerklik, işin kapsamı),

- Grup/lider ilişkileri (Görev dayanışması, grup kaynaşması, liderin saygınlığı, lider-grup ilişkisi, katılımcı liderlik, lider/yetki yapısı),

• Örgütsel özellikler (Örgütteki merkezileşme derecesi ve örgütün büyüklüğü).

Allen ve Meyer (1990: 3) tarafından ana hatları çizilen bir örgütsel bağlllık modelinde, sırasıyla "duygusal bağ lllık", "devam bağl1lığı" ve "normatif bağl1lık" olmak üzere örgütsel bağlllı̆̆ olduğunun ve bu unsurlar arasındaki ortak yönün çalışanın organizasyona devamsızlığını azalttığının belirtilmesidir. Bununla birlikte duygusal bağlanma eğiliminin; kişisel özellikler, işin özellikleri, yapısal faktörler ve işteki deneyimler olmak üzere dört kategoriye ayrıldığı da öne sürülmektedir. Bunlardan en önemlisi iş yaşantılarının çalışanların kurum içinde rahat hissetmeleri için psikolojik ihtiyaçları karşılayan deneyimleri ve iş rolü bileşenlerini gösteren güçlü kanıtlar sağlamasıdır (Allen ve Meyer, 1990: 4).

Örgütün amaçlarını ve değerlerini kuvvetli bir şekilde kabullenerek ve örgütün bir parçası olarak kalmayı isteyerek duygusal bağlılıkla çalışan birey, istenen bir mutluluk durumuna ulaşmaktadır (Baysal, vd., 214: 139). 


\section{A. Diken- N. Koçyiğit - E. Ö. Topaloğlu - A. Yılmaz 11/4 (2019) 2698-2716}

Ölçüm'e göre devam bağlılığında iş gören, örgütte kalmayı bir zorunluluk olarak görmektedir ki örgüte fazlasıyla yatırım yaptığını, zaman ve çaba harcadığını düşünmektedir. Yani kişinin örgütte çalışmaya devam etmesinin sebebi yaşaması muhtemel maddi kayıplarıdır (Ölçüm, 2004: 95). Balay'a göre yaş, görev süresi, terfi olanakları ile ödemeden sağlanan tatmin, örgütten ayrılma isteği ve iş gören devri devam bağımlılığı ile ilişkilidir (Balay, 2000: 76).

Taşkın'ın aktardığına göre Meyer ve Allen normatif bağlılığı, duygusal ve devamlılık bağlılığına ilaveten ahlaki niteliği de kapsayan üçüncü yöntem olarak oluşturmuşlardır. Normatif bağlılık, örgüte sadık olma meyili ile bağlantılı olup, örgütün görev, ülkü, amaç ve icraatları ile ahenk içinde olan inanç ve normları içermektedir (Taşkın, 2010: 39). Normatif bağlllık, iş görenlerin ahlaki bir vazife sorumluluğu ve örgütten ayrılmamaları gerektiğine inanmaları neticesinde oluşan bağlılık türüdür (Özdevecioğlu, 2003:114).

\section{3. İș Tatmini}

Yönetim düşünce sistemine göre, bir işletmenin başarısı, kârlılık, pazar payı vb. değişkenler kadar, iş görenlerin iş tatmini de önem arz etmektedir. Bu nedenle "iş tatmini" 1940'lı yıllardan beri yönetim alanında üzerinde en fazla araştırma yapılan konulardan biri olmuş, hatta son 70 yıldır konu ile ilgili dört binin üzerinde çalışma yapıldığı çeşitli yazarlar tarafından dile getirilmiştir. "İş tatmini nedir?" sorusu tartışılırken ilk önce kelime anlamının ne olduğuna değinilmelidir. TDK (2018)'a göre "tatmin, istediği bir şeye ulaşarak hoşnut olmak, rahatlamak, doyurulmak" anlamındadır. İş tatmini, insanların yaşamında hem ekonomik hem de psikolojik açıdan büyük bir öneme sahiptir ve bu kelimenin ne anlama geldiği çoğu araştırmaya konu olmuştur. Araştırmacılar arasında en yaygın olarak kullanılan "iş tatmini tanımları" Hoppock, Locke ve Vroom'un tanımlarıdır. 1930'larda Hoppock'un iş tatmini tanımı, "kişinin gerçekten işimde tatmin oluyorum, söylemesine sebep olan fizyolojik, psikolojik ve çevresel koşulların karışımıdır" şeklindedir (Sığrı ve Basım, 2006: 133). Davis (1988) iş tatminini, çalışanların işlerinden duydukları hoşnutluk ya da hoşnutsuzluk şeklinde ifade etmektedir (Aşık, 2010: 37). Vroom (1967)'a göre iş tatmininin, iş yaşantılarına karşı duygusal bir tepki olarak tanımlaması da yapılmaktadır (Avşaroğlu vd., 2005: 117, Vroom, 1967: 99).

İş tatmini üzerine yapılan tanımlamalardan çıkarılan ortak noktalar bulunmaktadır. İş tatmini, çalışanın işinden duyduğu mutluluk ve hoşnutluktur (Eker, 2006: 49). Çalışanların yaptıkları işler hakkında olumlu ve olumsuz duyguların derecesi olarak da çıkarım yapılmaktadır (Bakan ve Büyükmeşe, 2004: 6-7). İş tatmini denilince, çalışanın işten aldığı maddi kazanç ile işinden aldığı zevk ile birlikte ortaya çıkan mutluluk akla gelmektedir (Eren, 1993; 145).

İş tatmini 1930'lardan itibaren popüler hale gelmiş, pek çok çalışma alanına konu olmuş ve kuramsal teorilerle desteklenmiştir. İlk olarak, iş tatminini açıklamak amacıyla Abraham Maslow'un ihtiyaçlar hiyerarşisinden faydalanılmıştır. İnsan ihtiyaçları fizyolojik, güvenlik, sevgi, saygı ve kendini gerçekleştirme olarak sırasıyla sınıflandırılmıştır. Önceliği olan ihtiyaçlar giderilmeden diğer aşamalara geçilmemektedir. Yani öncelikli tatmin sağlanmadan başka bir ihtiyaç giderilememektedir (Durmuş ve Günay, 2007:140).

İş tatminin ilişkilendirildiği ikinci yaklaşım Herzberg'in İki Etmen Teorisi'dir. Herzberg, yapmış olduğu çalışmada iş yerinde hoşnutsuzluk derecesini arttıran ve azaltan etmenleri bulmak istemiştir. Çalışma ortamındaki etmenleri güdüleyici ve hijyen etmenler olarak gruplandırmıştır. Güdüleyici etmenlerin (iş başarma, tanınma, sorumluluk) kişinin üzerinde etkisi vardır. Hijyen etmenlerin (işletme yönetim ve denetim politikası, ücret ve çalışma koşulları vb.) çalışanın üzerinde etkisi yok iken, var olmadığı durumda tatminsizliğe yol açtığı görülmektedir (Özer ve Bakır, 2003; 118). İhtiyaçlar temel motivasyon faktörüdür ki bazı faktörler motivasyon sağlamaz iken tatminin var olması için gereklidir (Samadov, 2006: 40).

Locke'un amaç teorisine göre, kişilerin amaçları, motivasyonunu belirler ve burada belirleyici olan amaçlara ulaşılabilirlik derecesidir. Hedefin belirgin olması zorunluluğunun ve amaca bağlılığın iş performansını yükselttiğini savunmaktadır. Bu nedenle çalışanlara zor ama ulaşılabilir hedefler verilmesi gerekmektedir (Öztürk ve Şahbudak, 2016: 495).

Mc Clelland'ın Başarma İhtiyacı Teorisi, kişilerin başarma, güç elde etme ve ilişki kurma ihtiyaçlarından bahsetmektedir. Bu teoriye göre bazı ihtiyaçlar kişiyi motive etmektedir ki bu ihtiyaçlar ne kadar kuvvetli ise, bunları bertaraf edici davranışlara yönelim o derece yüksektir (Steers vd., 2004: 381). 


\section{A. Diken- N. Koçyiğit - E. Ö. Topaloğlu - A. Yılmaz 11/4 (2019) 2698-2716}

Alderfer'in Varoluş, İlgililik ve Büyüme teorisi ise, Maslow'un belirlediği ihtiyaçları, var olma, gelişme ve ilişki olmak üzere üç grupta toplamıştır. Bu yüzden ihtiyaçlar giderilmediğinde bir alt düzeyde gereksinim ortaya çıkmaktadır. Buna da hayal kırıklığı-çekinme denilmektedir. Yani kişi bir üst ihtiyacını karşılamada sıkıntı çekerse alt düzeyde ihtiyacını gerçekleştirecektir (Semerci, 2005: 16).

Eşitlik teorisi, çalışanların iş yerlerinde yaşadıkları veya hissettikleri adaletsiz durumlara nasıl tepki gösterdiklerini açıklamaktadır. Bu durum karşısında çalışanların bilişsel ve davranışsal tepkilerini anlamaya çalışmaktadır. Adams tarafından geliştirilen teoride ödüllendirmenin davranışa etkisi değerlendirilmektedir (Öztürk ve Şahbudak, 2016: 495).

Vroom'un Bekleyiş Teorisi, çalışanların davranışlarını rasyonel olarak değerlendirmektedir. Bu nedenle iş görenler kendilerini ödül ve cezaya götüren davranışlara yönelmektedir. Başaracaklarına inandıkları işleri yapmayı arzulamaktadırlar (Steers vd., 2004: 382).

Bu zamana kadar yapılan çalışmalar sonrasında modern örgütlerde iş tatmini bağımsız değişken olarak ele alınmaktadır ve üzerine geliştirici çalışmalar yapılmıştır. Nitekim kişilerin yaşam ve çalışma kalitesi arttırılarak, aldığı haz ve iş tatmininin artması sağlanmaktadır (Telef, 2011: 93).

İş tatminini etkileyen etmenleri ise içsel ve dışsal olarak ikiye ayırmak mümkündür. İçsel etmenler; kişilerin demografik özelliklerinden; yaş, cinsiyet, medeni durum ve kişilik özellikleri, sosyo-kültürel çevre, çalışanların mesleki düzeyleri, çalışanların hizmet süreleri, çalışanların zekâları ve yetenekleridir. İş tatminini etkileyen dışsal etmenler; çalışma ortamının fiziksel özellikleri, iş ve işin özellikleri, birlikte çalıştıkları iş arkadaşları, iş yerindeki ast-üst ilişki durumu, çalışanların kararlara katılım durumu, örgüt içerisindeki iletişim, geri bildirim, ücret ve terfi olanaklarıdır (Samadov, 2006: 15-32). Örneğin kişinin kendini kötü ve olumsuz bir duygu durumu içerisinde bulmasının nedeni mesai arkadaşının söylediği kötü bir söz olabileceği gibi gece gördüğü kabus da olabilir. İşle ilgili etmenler de bu duygu değişkenliklerine zemin hazırlayan dışsal faktörler arasındadır. Bu varsayım iş tatmini araştırmalarının temeline kişisel faktörleri ve dışsal etkenleri koymayı gerektirmektedir (Dikmen, 1995: 116). Bu noktada örgütsel davranış açısından en önemli tutumlardan biri olan bireyin işine karşı geliştirdiği tutumları ifade eden iş tatmini karşımıza çıkmaktadır. Eğer çalışanın işine karşı geliştirdiği tutumlar olumlu ise çalışanların iş tatmin düzeylerinin yüksek, eğer olumsuz ise iş tatmin düzeylerinin düşük olduğu görülür (Özkalp ve Kırel, 2004: 75).

Spector, iş tatmininin önemini üç faktörde açıklamaktadır (Spector, 1997):

- Örgütler insancıl değerlerle yönetilebilmektedir. Bu şekil davranıldığında çalışanlarda zihinsel dinginlik ve duygusal tatmin elde edilmektedir.

- İş tatmininin dereceleri örgütsel faaliyetleri etkilemektedir.

- İş tatmini, örgütsel faaliyetlerin birer göstergesidir.

Buna göre iş tatmininin etkilerini kişiler açısından, örgütler açısından ve yöneticiler açısından ele almak daha doğru olacaktır. Kişi açısından iş tatmininin yüksek olması kişinin mutlu olmasına neden olmaktadır. Örgüt açısından iş tatmininin yüksek olması çalışanların beklentilerini karşılayabilmesi ve çalışanların süreklilik göstermesinde etkili olmaktadır. İş tatmini yüksek örgütlere eleman bulmak her zaman kolay olacaktır. Yönetici açısından iş tatmini, çalışanların performansları ve verimlilikleri üzerinde etkilidir. İş tatmini yüksek olduğu zaman işe devamsızlıklar azalmakta, performans düşüklüğü yaşanmamakta, sendikalaşmalar ve işten ayrilmalar meydana gelmemektedir (Eker, 2006: 58-60). Bu durum hem iş gören hem de işletme açısından başarıyı getirmektedir. Düşük tatmin ise işin yavaşlaması, işten ayrılmalar ve düşük çalışma performansı gibi olumsuzluklara yol açmaktadır. Bu nedenle işverenler belirli periyodlarla iş görenlerin iş tatminlerini ölçmelidirler. Sonuçların olumlu çıkması halinde, bu durumu koruyucu önlemler geliştirilmeli, olumsuz çıkması durumunda ise; iş tatminini arttıracak çözümler üretilmelidir. İş tatmini işletmeler için verimlilik ve kalite artışı ya da azalışı demektir. İş görenler için de iş ve özel yaşamlarında mutluluk ya da mutsuzluk kaynağıdır (Aykaç, 2010: 10). Bu sebeplerden ötürü iş tatmini iş hayatında önem arz etmektedir.

\section{4. Örgütsel Bağlılık ve Örgütsel Destek Arasındaki İlişkide İş Tatmininin Aracılık Rolü}

İş görenin iş sonunda ulaştığı haz ne kadar yüksek ise, işinden sağladığ tatmin o kadar yüksek demektir. Örgütsel bağlılık, işe yönelik sonuçlarla yakından ilişkili olduğundan işin etkinliğini açıklamada ve arttırmada önemli rol oynamaktadır (Mathieu ve Zajac, 1990). Örgütsel bağlılık; örgüt adına dikkate değer çaba gösterme ve sürdürme isteği olarak tanımlanmaktadır. Buna göre iş tatmini, iş görevlerini ve tanımlamalarını 
A. Diken- N. Koçyiğit - E. Ö. Topaloğlu - A. Yılmaz 11/4 (2019) 2698-2716

belirlemede geniş bir çerçeve sunmaktadır ve örgütsel bağlılığa bu çerçevede olumlu girdiler sağlamaktadır. $\mathrm{Bu}$ açıklamadan hareketle örgütsel bağlllık ve iş tatmini arasında doğrudan ilişki olması beklenmektedir. Çünkü iş tatmini ne kadar yüksek olursa, örgütsel bağlllık o derece yüksek olacaktır. Bir çalışan işinden tatmin alırsa, o örgüte olan bağllığı artacaktır. Eğer çalışan işinden memnun değil ise, örgüte olan bağlllığ1 azalacaktır (Ülbeği ve Yalçın, 2016: 83). Eisenberger vd. (1997: 812-820), algılanan örgütsel destek ve iş tatmini arasında olumlu ve güçlü bir ilişki saptamışlardır. Örgütün çalışanlarını birer değer olarak kabul etmesi, çalışanların örgüt ile olumlu duygusal bağ kurmasına neden olmaktadır. Örgüt değerlerinin çalışanların esenliğini ve mutluluğunu dikkate alması çalışanların iş tatminlerini doğrudan etkilemektedir (Turunç ve Çelik, 2010: 185).

Literatür araştırmasından hareketle çalışmada amaç, öğretmenlerin örgütsel desteğe ilişkin algıları ve örgütsel bağlılıkları arasındaki ilişkinin varlığında iş tatmininin aracı rolünü belirlemektir. Öğretmenlerin okul içinde algıladıkları desteğin ve kuruma bağlılıklarının cinsiyet, yaş, branş, vb. demografik özellikler açısından farklılık gösterip göstermediğini ortaya koymak hedeflenmiştir. Öğretmenlerin kuruma aidiyet açısından kişisel çabalarının yanı sıra, çalıştıkları kurumun yöneticileri, bağlı olunan bakanlık, sendikalar, vb. kurumların öğretmenlerin algıladıkları örgütsel destek ve bağlılık düzeyinin artmasına ve dolayısıyla iş tatminlerinin yükselmesine yönelik ne tür faaliyetler içinde oldukları ve olmaları gerektiğini tespit etmek bir diğer amaçtır. İş tatminini etkileyen faktörlerin; performans ölçümü, aldıkları puanlar, vb.nin belirlenip, iş tatmini yüksek olup, eğitimin kalitesinin artırılması için görev üstü davranışlarda bulunan, gönüllü faaliyetlere katılan öğretmenlerin bu algısında örgütsel desteğin ve bağlllı̆̆ın etkisini ortaya koymak hedeflenmiştir. Araştırmanın öğretmenlik mesleğinin gelişmesi, öğretmenlerin ne tür örgütsel destek beklediklerinin ortaya çıkarılması, eğitim kalitesinin artması, nitelikli öğrenci ve mezunların yetişmesi ve iş gören kalitesinin artması açısından önemli olduğu düşünülmektedir.

\section{ARAŞTIRMANIN YÖNTEMI}

Araştırma verilerinin toplanmasında anket tekniği kullanılmıştır. Anketlerden elde edilen verilerin analizinde SPSS (Statistical Package for the Social Sciences 21) programı kullanılmış olup, ölçeklerin geçerlik ve güvenirlik analizleri yapılmıştır.

Değişkenlere ilişkin veriler analize tabi tutularak frekans tabloları oluşturulmuş, Ki-kare analizleri, Anova testleri, normallik testleri, faktör analizleri yapılmış ve araştırmanın hipotezlerinin testinde yapısal eşitlik modellemesinden yararlanılmıştır.

\subsection{Araştırma Modeli}

Modelde, algılanan örgütsel destek, örgütsel bağlllık ve iş tatmini olmak üzere toplam üç değişken bulunmaktadır. Algılanan örgütsel destek modelin bağımsız değişkenini, örgütsel bağlılık bağımlı değişkenini, iş tatmini ise aracı değişkeni oluşturmaktadır. Bu doğrultuda araştırmanın modeli aşağıdaki gibidir.

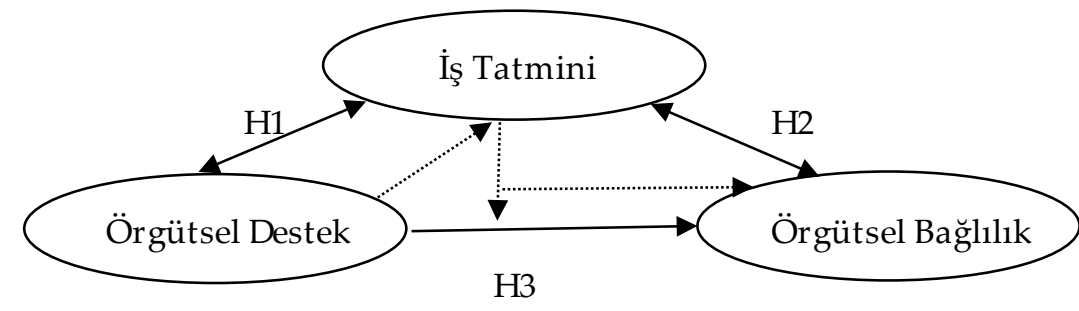

Şekil 1. Araştırma Modeli

Araştırma modeline bağlı oluşturulan hipotezler şöyledir:

H1: İş tatmini ile örgütsel bağlılık arasında pozitif bir ilişki vardır.

H2: İş tatmini ile örgütsel destek arasında pozitif bir ilişki vardır.

H3: Örgütsel destek ile örgütsel bağlılık arasındaki ilişki de iş tatmininin etkisi vardır. 


\section{2. Örneklem}

Çalışmanın evrenini Konya İli Karatay, Meram ve Selçuklu ilçelerinde bulunan, 2017-2018 eğitim öğretim yılı içerisinde resmi ve özel ortaöğretim kurumlarında görev yapan öğretmenler oluşturmaktadır. İl Milli Eğitim Müdürlüğü'ne araştırma izni için başvurulan dilekçe sonucu, 2017-2018 eğitim öğretim yılında il genelinde ortaöğretim kurumlarında; 7973'ü resmi okulda, 1297'si özel okulda olmak üzere toplam 9270 öğretmenin çalıştığı bilgisine ulaşılmıştır. Çalışmada maliyet ve zaman da dikkate alınarak araştırma evrenindeki tüm kişilere ulaşılmasının mümkün olmaması sebebiyle basit tesadüfi örnekleme yöntemi tercih edilmiştir. Tablo 1 ihtiyaç duyulan örneklem büyüklüğü için bir veri sunmaktadır.

\section{Tablo 1. Farklı Evren Büyüklükleri ve Hata Düzeyleri İçin İhtiyaç Duyulan Örneklem Büyüklükleri}

\begin{tabular}{|l|l|l|l|r|r|r|}
\hline \multicolumn{2}{|l|}{$\boldsymbol{\alpha}=\mathbf{0 , 0 5}$ için örneklem büyüklükleri } \\
\hline \\
\hline
\end{tabular}

Kaynak: Baş, 2006: 47.

Tablo 1'de gösterildiği üzere \%95 güven aralığında, + - \%3, + - \%5, + - \%10 örnekleme hataları için farklı evren büyüklüklerine karşılık gelen örneklem büyüklüklerine göre, örneklem hatasını azaltmak için araştırmaya katılan kişiden oluşan örneklem sayısı temsil edilebilir yeterlikte bulunmuştur.

Verilerin toplanması için anket formu yüz yüze katılımcılara uygulanmıştır ve katılımcılardan soruları cevaplamaları istenmiştir. Evrenin içinden ulaşılabilen ve yüz yüze görüşülen 300 öğretmen çalışmanın örneklemini oluşturmaktadır. Tablo 2. demografik verilere ilişkin sonuçları göstermektedir.

Tablo 2. Demografik Bulgular

\begin{tabular}{|c|l|r|r|}
\hline & & Frekans & Yüzde \\
\hline \multirow{2}{*}{ Cinsiyet } & Kadın & 132 & 44 \\
& Erkek & 168 & 56 \\
& Toplam & 300 & 100 \\
\hline & $20-30$ & 49 & 16,3 \\
& $31-40$ & 90 & 30 \\
Yaş & $41-50$ & 109 & 36,3 \\
& $51+$ & 52 & 17,3 \\
& Toplam & 300 & 100 \\
\hline Öğrenim Durumu & Ön Lisans & 5 & 1,7
\end{tabular}


A. Diken- N. Koçyiğit - E. Ö. Topaloğlu - A. Yılmaz 11/4 (2019) 2698-2716

\begin{tabular}{|c|c|c|c|}
\hline & $\begin{array}{l}\text { Lisans } \\
\text { Yüksek Lisans } \\
\text { Doktora } \\
\text { Toplam }\end{array}$ & $\begin{array}{r}222 \\
72 \\
1 \\
300 \\
\end{array}$ & $\begin{array}{r}74 \\
24 \\
0,3 \\
100 \\
\end{array}$ \\
\hline Kidem & $\begin{array}{l}\text { 1-10 Y⿺l } \\
11-20 Y_{11} \\
21 Y_{1} 1 \text { ve üzeri } \\
\text { Toplam }\end{array}$ & $\begin{array}{r}87 \\
107 \\
106 \\
300\end{array}$ & $\begin{array}{r}29 \\
35,7 \\
35,3 \\
100 \\
\end{array}$ \\
\hline $\begin{array}{c}\text { Şuan Görev Yapılan Okuldaki Hizmet } \\
\text { Süresi }\end{array}$ & $\begin{array}{l}1 \text { Yildan az } \\
\text { 1-5 Y1l } \\
6-10 Y_{11} \\
\text { 11-20 Y⿺l } \\
21 Y_{11} \text { ve üzeri } \\
\text { Toplam }\end{array}$ & $\begin{array}{r}34 \\
138 \\
83 \\
27 \\
18 \\
300\end{array}$ & $\begin{array}{r}11,3 \\
46,0 \\
27,7 \\
9 \\
6 \\
100\end{array}$ \\
\hline Çalışılan Okul Türü & $\begin{array}{l}\text { Genel Lise } \\
\text { Anadolu Lisesi } \\
\text { Fen Lisesi } \\
\text { Meslek Lisesi } \\
\text { Toplam }\end{array}$ & $\begin{array}{r}38 \\
86 \\
1 \\
175 \\
300\end{array}$ & $\begin{array}{r}12,7 \\
28,7 \\
0,3 \\
58,3 \\
100\end{array}$ \\
\hline Kurum Türü & $\begin{array}{l}\text { Özel } \\
\text { Devlet } \\
\text { Toplam }\end{array}$ & $\begin{array}{r}37 \\
263 \\
300\end{array}$ & $\begin{array}{r}12,3 \\
87,7 \\
100\end{array}$ \\
\hline Branş & $\begin{array}{l}\text { Fen Bilimleri } \\
\text { Sosyal Bilimler } \\
\text { Güzel Sanatlar } \\
\text { Meslek Dersleri } \\
\text { Toplam } \\
\end{array}$ & $\begin{array}{r}73 \\
82 \\
16 \\
129 \\
300 \\
\end{array}$ & $\begin{array}{r}24,3 \\
27,3 \\
5,3 \\
43 \\
100\end{array}$ \\
\hline İdari Görev & $\begin{array}{l}\text { Sadece İdari Görev } \\
\text { Hem İdari Görev Hem } \\
\text { Öğretmenlik } \\
\text { Sadece Ö̆ğretmenlik } \\
\text { Toplam }\end{array}$ & $\begin{array}{r}13 \\
26 \\
261 \\
300\end{array}$ & $\begin{array}{r}8,7 \\
87 \\
100 \\
\end{array}$ \\
\hline
\end{tabular}

Araştırmaya katılan 300 öğretmenin \%44'ü kadın \%56'sı erkektir. Yaş gruplarına göre incelendiğinde ise 2030 yaş grubu arasında 49 kişi bulunurken, 31-40 yaş arasında 90 kişi, 41-50 yaş arasında 109 kişi bulunmakta ve 51 yaş ve üzerinde ise 52 kişi yer almaktadır.

Katılımcıların öğrenim durumlarına bakıldığında ise; \%1,7'si (5 kişi-41-50 yaş aralığında ve 51 yaş ve üzeri olanlar) ön lisans mezunu iken, \%74'ü lisans mezunu (222 kişi), \%24'ü (72 kişi) yüksek lisans mezunudur, buna karşılık yalnızca 1 katılımcı doktora mezunu olduğunu belirtmiştir.

Katılımcıların kıdem durumları incelendiğinde ise; 1-10 yıl arası kıdeme sahip olanlar \%29'luk (87 kişi) kesimi oluştururken, 11-20 yıl arası kıdeme sahip olanlar \%46'lık (107 kişi), buna karşıllk 21 yıl ve üzeri kıdemi olanlar ise \%35,3'lük (106 kişi) kesimi oluşturmaktadır.

Hali hazırda görev yaptıkları okullardaki hizmet süreleri kıyaslandığında; \%11,3'ü (34 kişi) 1 yıldan az süredir görev yaparken, \%46'sı (138 kişi) 1-5 yıl arası, \%27,7'si (83 kişi) 6-10 yıl arası, \%9'u (27 kişi) 11-20 yıl arası, \%6'sı (18 kişi) ise 20 yıl ve üzeri süredir aynı kurumda görev yaptıklarını belirtmişlerdir.

Eğitim verdikleri okul türlerine bakıldığında; \%12,7'si (38 kişi) Genel liselerde, \%28,7'si (86 kişi) Anadolu liselerinde, \%58,3’u (175 kişi) Meslek liselerinde görev yaparken yalnızca 1 katılımcı Fen Lisesi'nde görev yapmaktadir. 
A. Diken- N. Koçyiğit - E. Ö. Topaloğlu - A. Yılmaz 11/4 (2019) 2698-2716

Görev yapılan kurumların özel-devlet kıyaslaması yapıldığında elde edilen sonuçlara göre; \%12,3'ü (37 kişi) özel okulda görev yaparken, \%87,7'si (263 kişi) devlet okulunda görev yapmaktadır.

Öğretmenlerin branşları karşılaştırıldığında; 73 öğretmen Fen Bilimleri branşında iken, 82 öğretmen Sosyal Bilimler, 16 öğretmen Güzel Sanatlar, 129 öğretmen ise Meslek Dersleri branşında eğitim vermekte olduklarını belirtmişlerdir.

İdari görevleri sorulduğunda; 13 öğretmen "Sadece idari görevdeyim" yanıtını verirken, 26 öğretmen "Hem idari görev yapıyorum hem de öğretmenlik yapıyorum" demiş, buna karşıllk 261 öğretmen ise "Sadece öğretmenlik yapıyorum" yanıtını vermişlerdir.

\subsection{Veri Toplama Araçları}

Veri toplamı aracı olarak kullanılan anketin ilk bölümünde katılımcılara ilişkin demografik veriler (yaş, cinsiyet, mesleki kıdem, bulunulan okuldaki hizmet süresi, eğitim düzeyi, okul türü, branş ve idari görevin olup olmadığı) yer almaktadır.

İş tatminine ilişkin toplam 20 soru bulunmaktadır. Dawis, vd. (1967)'nin geliştirdiği Minessota İş Tatmini Ölçeği'nin, Baycan (1985) tarafından yapılan Türkçe uyarlamasının geçerlik ve güvenilirlik çalışmalarının yapıldığı (Yelboğa, 2007: 6) formu, Başaran (2017)'ın çalışmasından alınarak araştırmada kullanılmıştır. Ölçek 5'li likert tipindedir (1=hiç memnun değilim, 5=çok memnunum).

Öğretmenlerin örgütsel destek algılarını ölçmek için Eisenberger, vd. nin geliştirdiği ve Selçuk (2003) tarafından Türkçeye çevrilen "algılanan örgütsel destek ölçeği", Süzerler (2013) 'in çalışmasından alınarak kullanılmıştır. Ölçek 5'li likert tipindedir (1=hiç katılmıyorum, 5=tamamen katılıyorum).

Öğretmenler için örgütsel bağlılık ölçeği, geçerlik ve güvenirlik çalışmasının yapıldığı Üstüner (2009)'in çalışmasından alınmıştır. Ölçek 5'li likert tipindedir (1=hiç katılmıyorum, 5=tamamen katılıyorum).

Ölçeklerin yapı geçerliliği faktör ve güvenilirlik analizleri ile test edilmiştir. Verilerin analizinde SPSS (Statistical Package for the Social Sciences 21) programı kullanılmıştır. Yapılan güvenilirlik analizi sonucunda 20 maddelik iş tatmini ölçeğinin Cronbach Alpha değeri 0,915 olarak tespit edilmiştir. Tüm maddeler arasında madde toplam korelasyonlarının 0,4'ün altında olduğu madde bulunmadığı tespit edilmiştir. Güvenilirlik analizinin ardından faktör analizi gerçekleştirilmiştir. Bileşen sınırlaması yapılmadan gerçekleştirilen faktör analizinden elde edilen veriler incelendiğinde özdeğeri 1'in üzerinde bulunan 4 bileşenli faktör yapısı tespit edilmiştir.

Tablo 3. İş Tatmini Ölçeği Faktör Analizi Sonuçları

\begin{tabular}{|l|c|c|c|}
\hline \multirow{2}{*}{ Bileşenler } & \multicolumn{3}{|c|}{ Öz Değerler } \\
\cline { 2 - 4 } & Toplam & \% Açıklanan Varyans & $\begin{array}{c}\text { \% Kümülatif Açılana } \\
\text { Varyans }\end{array}$ \\
\hline 1 & 7,854 & 39,271 & 39,271 \\
\hline 2 & 1,757 & 8,786 & 48,057 \\
\hline 3 & 1,305 & 6,526 & 54,583 \\
\hline 4 & 1,067 & 5,337 & 59,921 \\
\hline
\end{tabular}

Faktör analizinde elde edilen Kaiser Meyer Olkin değeri 0,907'dir. KMO analizinde 0.50 'den düşük değerler kabul edilemez düzeyi ifade ederken, 0.90 'lar düzeyindeki KMO değerleri çok iyi kabul edilmektedir.

Ancak faktör yükleri dağılımı incelendiğinde ise 3. ve 4. bileşenlerin altında yer alan madde sayılarının 3' ün altında olması sebebiyle ve her bir bileşenin en azından 3 maddeyi yordaması kuralına bağlı kalarak, öz değerleri $1,5^{\prime}$ in altında olan faktörler çıkarılmış ve madde bileşen sayısı $2^{\prime}$ ye sabitlenerek analiz tekrarlanmıştır. 
A. Diken- N. Koçyiğit - E. Ö. Topaloğlu - A. Yılmaz 11/4 (2019) 2698-2716

Tablo 4. İş Tatmini Ölçeği Faktör Yükleri

\begin{tabular}{|c|c|c|c|c|c|c|c|}
\hline \multirow{2}{*}{\multicolumn{2}{|c|}{ Bileşenler }} & \multicolumn{3}{|c|}{ Başlangıç Öz Değerleri } & \multicolumn{3}{|c|}{ Rotasyon Sonrası Değerler } \\
\hline & & \multirow{2}{*}{$\begin{array}{l}\text { Toplam } \\
7,854 \\
\end{array}$} & \multirow{2}{*}{\begin{tabular}{|c|}
$\begin{array}{c}\% \\
\text { Açılanan } \\
\text { Varyans }\end{array}$ \\
39,271 \\
\end{tabular}} & \multirow{2}{*}{$\begin{array}{c}\text { \% } \\
\text { Kümülatif } \\
\text { Açıklana } \\
\text { Varyans } \\
39,271\end{array}$} & \multirow{2}{*}{$\begin{array}{l}\text { Toplam } \\
5,363 \\
\end{array}$} & \multirow{2}{*}{$\begin{array}{c}\text { \% } \\
\text { Açıklanan } \\
\text { Varyans }\end{array}$} & \multirow{2}{*}{$\begin{array}{c}\% \\
\text { Kümülatif } \\
\text { Açılana } \\
\text { Varyans } \\
26,814\end{array}$} \\
\hline & 1 & & & & & & \\
\hline & 2 & 1,757 & 8,786 & 48,057 & 4,249 & 21,243 & 48,057 \\
\hline
\end{tabular}

2 faktörlü yapının toplam açıklanan varyansı \%48,05 dir. Faktör dağılımı varimax rotasyon tekniği ile gerçekleştirilmiştir.

KMO değerinin $0,8^{\prime}$ in üzerinde olduğu ve Bartlett's testinin ise $0,05^{\prime}$ ten küçük olması sebebiyle, yapılan faktör analizi sonucunda elde edilen modelin istatistiksel olarak anlamlı olduğu sonucuna ulaşılmıştır.

Elde edilen faktör analizinin sonucunda elde edilen faktörlerin ayrı ayrı güvenilirlik analizleri yapılmıştır. Yapılan güvenilirlik analizleri ile kurulan faktör yapısının uygunluğu yeniden test edilmiştir. Faktörlerin tek başlarına Cronbach Alpha değerleri 0,6'nın üzerindedir ve her bir faktörün altında değerlendirilen maddelerin madde toplam korelasyon değerleri de 0,3 'ün üzerindedir.

DFA sonuçlarına göre, faktör yükleri $(\lambda) .35$ ile.80 arasında değişmektedir. Değişkenlerin faktör yükleri, ait olduğu faktör grubuna yaptıkları katkıyı gösterir. 0.60 ve üstü yük değeri yüksek; .30-.59 arası yük değeri orta düzeyde büyüklük olarak tanımlanabilir Ayrıca tüm maddelere ilişkin t değerleri anlamlıdır. Yapılan DFA, ölçeğin son halini 20 madde ve 2 alt boyut olarak mümkün kılmaktadır. Modele dâhil edilen tüm maddelerin model ile uyumlu olduğu söylenebilir.

Ölçme modellerinde yapının birleşme güvenilirliği kullanılan başlıca ölçümlerdendir ve genellikle .70 'ten yüksek değerler kabul edilebilirdir.

Tablo 5. İş Tatmini Ölçeği Uyum İndeksleri

\begin{tabular}{lccccccc}
\hline Model & $\chi^{2}$ & sd & $\chi^{2} / \mathbf{s d}$ & NFI & GFI & CFI & RMSEA \\
\hline 2 Faktörlü Yapı & 333,78 & 152 & 2,19 & 0,88 & 0,90 & 0,93 & 0,063 \\
\hline Ölçütler & & & $\leq 5$ & $\geq .85$ & $\geq .90$ & $\geq 0,90$ & $\leq .08$ \\
\hline
\end{tabular}

х2: Chi-Square Goodness of Fit, sd: Serbestlik Derecesi (df), NFI: Normed Fit Index, GFI: Goodness of Fit Index, CFI: Comperative Fit Index, RMSEA: Root Mean Square Error of Approximation

Modele ilişkin hesaplanan $\chi 2$ sd oranının 3'ten küçük olması mükemmel uyumun göstergelerindendir. CFI, GFI, NFI, RMSEA değerleri de gerekli ölçütleri sağlamıştır.

Böylece iş tatmini ölçeğinde yer alan 20 maddedeki 2 boyutlu yapının model-veri uyumuna sahip olduğu sonucuna ulaşılmıştır. Uyum indekslerine ait genel kriterler karşılaştırıldığında bu çalışmaya ait değerlerin kabul edilebilir ölçüler içerisinde olduğu görülmektedir.

Öğretmenlerin iş tatmini ölçeğine verdikleri yanıtlar incelendiğinde en fazla memnun olduklarını dile getirdikleri madde 4,17 ortalama ile "Öğrencileri yönlendirmek için fırsat verdiğinden" maddesi olurken, onu 4,15 ortalama ile "Başkaları için bir şeyler yapabildiğimi hissetmem açısından" maddesi takip etmektedir. En az memnun olunan madde ise 3,03 ortalama ile "Terfi imkanının olması yönünden" maddesidir.

Yapılan güvenilirlik analizi sonucunda 20 maddelik örgütsel destek ölçeğinin Cronbach Alpha değeri 0,931 olarak tespit edilmiştir. Tüm maddeler arasında madde toplam korelasyonlarının 0,5'in altında olduğu madde bulunmadığ 1 tespit edilmiştir.

Güvenilirlik analizinin ardından faktör analizi gerçekleştirilmiştir. Bileşen sınırlaması yapılmadan gerçekleştirilen faktör analizinden elde edilen veriler incelendiğinde özdeğeri 1'in üzerinde bulunan 3 bileşenli faktör yapısı tespit edilmiştir.

Elde edilen faktör analizinde elde edilen Kaiser Meyer Olkin değeri 0,920' dir. KMO analizinde 0.50 'den düşük değerler kabul edilemez düzeyi ifade ederken, 0.90 'lar düzeyindeki KMO değerleri çok iyi kabul edilmektedir. 
A. Diken- N. Koçyiğit - E. Ö. Topaloğlu - A. Yılmaz 11/4 (2019) 2698-2716

Tablo 6. Örgütsel Destek Ölçeği Faktör Yükleri

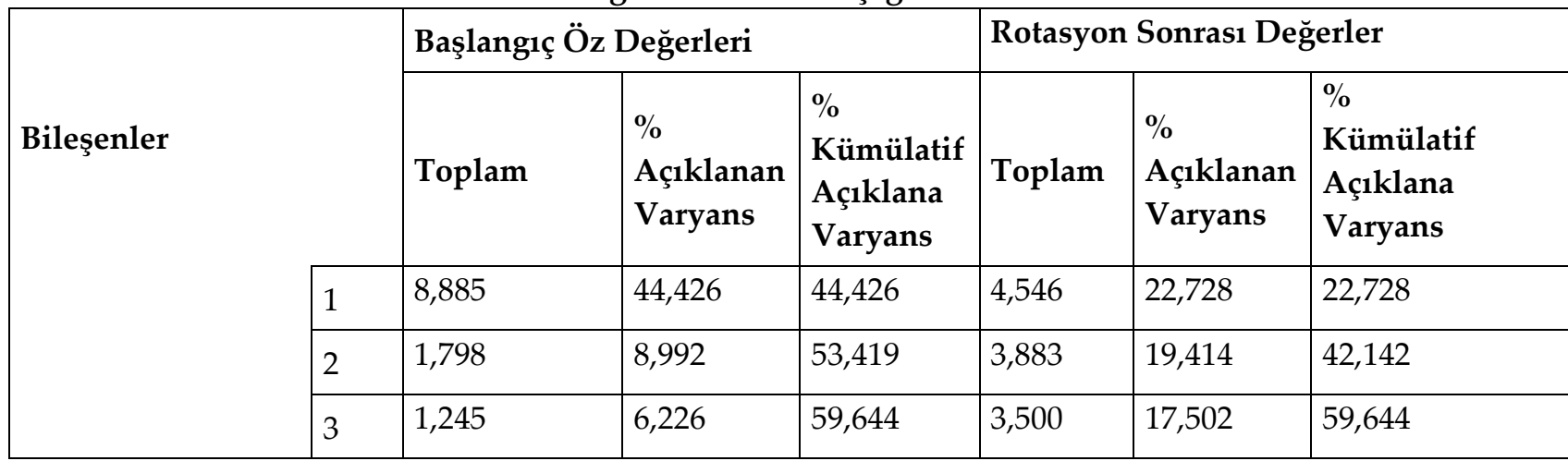

3 faktörlü yapının toplam açıklanan varyansı \%59,64'dür. Faktör dağılımı varimax rotasyon tekniği ile gerçekleştirilmiştir.

KMO değerinin 0,8'in üzerinde olduğu ve Bartlett's testinin ise $0,05^{\prime}$ ten küçük olması sebebiyle, yapılan faktör analizi sonucunda elde edilen modelin istatistiksel olarak anlamlı olduğu sonucuna ulaşılmıştır.

Faktör analizinin sonucunda elde edilen faktörlerin ayrı ayrı güvenilirlik analizleri yapılmıştır. Yapılan güvenilirlik analizleri ile kurulan faktör yapısının uygunluğu yeniden test edilmiştir. Faktörlerin tek başlarına Cronbach Alpha değerleri 0,6'nın üzerindedir ve her bir faktörün altında değerlendirilen maddelerin madde toplam korelasyon değerleri de 0,3 'ün üzerindedir.

DFA sonuçlarına göre, faktör yükleri ( $\lambda$ ) .50 ile.80 arasında değişmektedir. Değişkenlerin faktör yükleri, ait olduğu faktör grubuna yaptıkları katkıyı gösterir. 0.60 ve üstü yük değeri yüksek; .30-.59 arası yük değeri orta düzeyde büyüklük olarak tanımlanabilir. Ayrıca tüm maddeler ilişkin t değerleri anlamlıdır. Yapılan DFA, ölçeğin son halini 20 madde ve 3 alt boyut olarak mümkün kılmaktadır. Modele dâhil edilen tüm maddelerin model ile uyumlu olduğu söylenebilir. Ölçme modellerinde yapının birleşme güvenilirliği kullanılan başlıca ölçümlerdendir ve genellikle .70'ten yüksek değerler kabul edilebilirdir.

Tablo 7. Örgütsel Destek Ölçeği Uyum İndeksleri

\begin{tabular}{lccccccc}
\hline Model & $\chi^{2}$ & sd & $\chi^{2} / \mathbf{s d}$ & NFI & GFI & CFI & RMSEA \\
\hline $\begin{array}{l}3 \quad \text { Faktörlü } \\
\text { Yapı }\end{array}$ & 447,104 & 142 & 3,14 & 0,87 & 0,88 & 0,91 & 0,08 \\
\hline Ölçütler & & & $\leq 5$ & $\geq .85$ & $\geq .90$ & $\geq 0,90$ & $\leq .08$ \\
\hline
\end{tabular}

Х2: Chi-Square Goodness of Fit, sd: Serbestlik Derecesi (df), NFI: Normed Fit Index, GFI: Goodness of Fit Index, CFI: Comperative Fit Index, RMSEA: Root Mean Square Error of Approximation

Modele ilişkin hesaplanan $\chi 2$ sd oranının 5 'ten küçük olması uyumun göstergelerindendir. CFI, NFI, RMSEA değerleri de gerekli ölçütleri sağlamıştır. Sadece uyum iyiliği indeksi (GFI) değerinin kabul edilen kritik değerin altında olduğu görülmektedir. GFI için .90 veya daha üstü değerler, kabul edilebilir uyumu gösterir. Böylece örgütsel destek ölçeğinde yer alan 20 maddedeki 3 boyutlu yapının model-veri uyumuna sahip olduğu sonucuna ulaşılmıştır. Uyum indekslerine ait genel kriterler karşılaştırıldığında bu çalışmaya ait değerlerin kabul edilebilir ölçüler içerisinde olduğu görülmektedir.

Öğretmenlerin verdikleri cevaplar incelendiğinde; örgütsel destek ölçeğinde en fazla katılım gösterdikleri madde 3,90 ortalama ile "Öğrencileri yönlendirmek için fırsat verdiği için" maddesi iken, onu 3,89 ortalama ile "Başkaları için bir şeyler yapabildiğimi hissetmem açısından" maddesi takip etmektedir. En az katılım gösterilen madde ise 3,09 ortalama ile "Sağlanan özlük hakları beni tatmin eder" maddesidir.

Yapılan güvenilirlik analizi sonucunda 21 maddelik örgütsel bağlılık ölçeğinin Cronbach Alpha değeri 0,971 olarak tespit edilmiştir. Tüm maddeler arasında madde toplam korelasyonlarının 0,5 ' in altında olduğu madde bulunmadı̆̆ 
A. Diken- N. Koçyiğit - E. Ö. Topaloğlu - A. Yılmaz 11/4 (2019) 2698-2716

Güvenilirlik analizinin ardından faktör analizi gerçekleştirilmiştir. Bileşen sınırlaması yapılmadan gerçekleştirilen faktör analizinden elde edilen veriler incelendiğinde özdeğeri 1'in üzerinde bulunan 2 bileşenli faktör yapısı tespit edilmiştir. Ancak ikinci bileşenin altında toplanan madde sayısının 3' ün altında olması ve örgütsel bağlılık ölçeğinin literatürde de tek boyutta incelenmesi göz önünde bulundurularak tek boyutlu yapı tercih edilmiştir.

Elde edilen faktör analizinde elde edilen Kaiser Meyer Olkin değeri 0,968' dir. KMO analizinde $0.50^{\prime}$ den düşük değerler kabul edilemez düzeyi ifade ederken, 0.90'lar düzeyindeki KMO değerleri çok iyi kabul edilmektedir.

Tablo 8. Örgütsel Bağlılık Ölçeği Faktör Yükleri

\begin{tabular}{|c|c|c|c|c|c|c|c|}
\hline \multirow{4}{*}{ Bileşenler } & & \multicolumn{3}{|c|}{ Başlangıç Öz Değerleri } & \multicolumn{3}{|c|}{ Rotasyon Sonrası Değerler } \\
\hline & & Toplam & $\begin{array}{l}\text { \% } \\
\text { Açıklanan } \\
\text { Varyans }\end{array}$ & \begin{tabular}{|l}
$\%$ \\
Kümülatif \\
Açıklana \\
Varyans
\end{tabular} & Toplam & $\begin{array}{l}\text { \% } \\
\text { Açıklanan } \\
\text { Varyans }\end{array}$ & $\begin{array}{l}\% \\
\text { Kümülatif } \\
\text { Açıklana } \\
\text { Varyans }\end{array}$ \\
\hline & 1 & 13,419 & 63,898 & 63,898 & 13,419 & 63,898 & 63,898 \\
\hline & 2 & 1,012 & 4,821 & 68,719 & & & \\
\hline
\end{tabular}

KMO değerinin 0,8'in üzerinde olduğu ve Bartlett's testinin ise 0,05'ten küçük olması sebebiyle, yapılan faktör analizi sonucunda elde edilen modelin istatistiksel olarak anlamlı olduğu sonucuna ulaşılmıştır. Faktör analizinin sonucunda elde edilen tek faktörlü yapıda ayrı ayrı güvenilirlik analizleri yapılmasına gerek kalmamaktadir.

DFA sonuçlarına göre, faktör yükleri ( $\lambda$ ) .70 ile.85 arasında değişmektedir. Değişkenlerin faktör yükleri, ait olduğu faktör grubuna yaptıkları katkıyı gösterir. 0.60 ve üstü yük değeri yüksek; .30-.59 arası yük değeri orta düzeyde büyüklük olarak tanımlanabilir. Ayrıca tüm maddeler ilişkin t değerleri anlamlıdır. Yapılan DFA, ölçeğin son halini 21 madde ve tek boyut olarak mümkün kılmaktadır. Modele dâhil edilen tüm maddelerin model ile uyumlu olduğu söylenebilir.

Ölçme modellerinde yapının birleşme güvenilirliği kullanılan başlıca ölçümlerdendir ve genellikle .70'ten yüksek değerler kabul edilebilirdir.

Tablo 9. Örgütsel Bağlılık Ölçeği Uyum İndeksleri

\begin{tabular}{|c|c|c|c|c|c|c|c|}
\hline Model & $\chi^{2}$ & sd & $\chi^{2} / \mathrm{sd}$ & NFI & GFI & CFI & RMSEA \\
\hline $\begin{array}{ll}\text { Tek } & \text { Faktörlü } \\
\text { Yapı } & \end{array}$ & 452,823 & 172 & 2,63 & 0,92 & 0,87 & 0,95 & 0,074 \\
\hline Ölçütler & & & $\leq 5$ & $\geq .85$ & $\geq .90$ & $\geq 0,90$ & $\leq .08$ \\
\hline
\end{tabular}

ఒ2: Chi-Square Goodness of Fit, sd: Serbestlik Derecesi (df), NFI: Normed Fit Index, GFI: Goodness of Fit Index, CFI: Comperative Fit Index, RMSEA: Root Mean Square Error of Approximation

Modele ilişkin hesaplanan $\chi 2 / s d$ oranının 3'ten küçük olması mükemmel uyumun göstergelerindendir. CFI, NFI, RMSEA değerleri de gerekli ölçütleri sağlamıştır. Sadece uyum iyiliği indeksi (GFI) değerinin kabul edilen kritik değerin altında olduğu görülmektedir. GFI için .90 veya daha üstü değerler, kabul edilebilir uyumu gösterir.

Böylece örgütsel bağlılık ölçeğinde yer alan 21 maddedeki 1 boyutlu yapının model-veri uyumuna sahip olduğu sonucuna ulaşılmıştır. Uyum indekslerine ait genel kriterler karşılaştırıldığında bu çalışmaya ait değerlerin kabul edilebilir ölçüler içerisinde olduğu görülmektedir.

Öğretmenlerin verdikleri cevaplar incelendiğinde; örgütsel bağlılık ölçeğinde en fazla katılım gösterdikleri madde 3,61 ortalama ile "Kendimi tamamen bu okulun bir parçası olarak hissediyorum" maddesi iken, onu 3,49 ortalama ile "Okulumun istikrarlı ve gelişmeyi hedefleyen bir yapısının olduğunu düşünüyorum." 
A. Diken- N. Koçyiğit - E. Ö. Topaloğlu - A. Yılmaz 11/4 (2019) 2698-2716

maddesi takip etmektedir. En az katılım gösterilen madde ise 3,21 ortalama ile "Yönetimin bir parçası olduğum hissi benim bu okuldan ayrılmamı engelliyor." maddesidir.

\section{BULGULAR}

Yapısal eşitlik modeli sonuçlarına göre uyum indekslerinin iyi uyum düzeyine yakın olduğu görülmektedir. Analiz sonucuna göre model-veri uyumuna sahip olduğu sonucuna ulaşılmıştır. Model-veri uyum indeksleri Şekil 2'de gösterilmiştir.

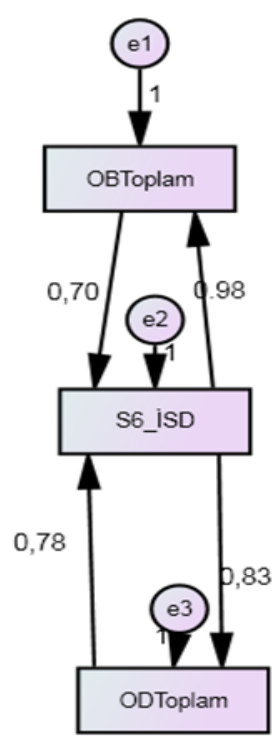

Şekil 2. Model-Veri Uyum İndeksleri

Model-veri uyum indeksine göre Tablo 10 araştırma modelinin uyum iyiliği değerlerini özetlemektedir.

Tablo 10. Araştırma Modelinin Uyum İyiliği Değerleri

\begin{tabular}{|c|l|l|l|l|l|l|l|l|}
\hline & $x^{2}$ & $\mathrm{df}$ & $\mathrm{x}^{2} / \mathrm{df}$ & GFI & NFI & IFI & CFI & RMSEA \\
\hline $\begin{array}{c}\text { Uyum } \\
\text { Değerleri }\end{array}$ & 58,156 & 15 & 3,87 & 0,895 & 0,903 & 0,905 & 0,905 & 0,09 \\
\hline $\begin{array}{c}\text { İyi Uyum } \\
\text { Değerleri }\end{array}$ & $\leq 3$ & $\geq 0,90$ & $\geq 0,90$ & $\geq 0,90$ & $\geq 0,95$ & $\leq 0,05$ \\
\hline $\begin{array}{c}\text { Kabul Edilebilir } \\
\text { Uyum } \\
\text { Değerleri }\end{array}$ & & $\leq 4-5$ & $0,89-0,85$ & $0,89-0,85$ & $0,89-0,85$ & $0,94-0,90$ & $0,06-0,08$ \\
\hline
\end{tabular}

$\mathrm{p}>.05, \mathrm{X}^{2}=$ Chi-Square (Ki-Kare); $\mathrm{df}=$ Degree of Freedom (Serbestlik Derecesi); GFI=Goodness Of Fit Index (İyilik Uyum İndeksi); IFI=Incremental Fit Index; CFI=Comparative Fit Index (Karşılaştırmalı Uyum İndeksi); RMSEA=Root Mean Square Error of Approximation (Yaklaşık Hataların Ortalama Karekökü).

Elde edilen sonuçlara göre; Örgütsel bağlılık algısının iş tatminine olumlu etkisi bulunmaktadır. $(\beta=0,701$; $\mathrm{p}=0,001)$.

Elde edilen sonuçlara göre; iş tatmininin örgütsel bağlllık algısına olumlu etkisi bulunmaktadır. $(\beta=0,987$; $\mathrm{p}=0,001)$.

Elde edilen sonuçlara göre; Örgütsel destek algısının iş tatminine olumlu etkisi bulunmaktadır. $(\beta=0,781$; $\mathrm{p}=0,001)$.

Elde edilen sonuçlara göre; iş tatmininin örgütsel destek algısına olumlu etkisi bulunmaktadır. $(\beta=0,825$; $\mathrm{p}=0,001)$. 
A. Diken- N. Koçyiğit - E. Ö. Topaloğlu - A. Yılmaz 11/4 (2019) 2698-2716

Tablo 11. Hipotez Sonuçları

\begin{tabular}{|c|c|c|c|c|c|c|c|c|}
\hline & Hipotezler & & Sonuç & $\begin{array}{l}\text { Tahmin } \\
(\beta)\end{array}$ & $\begin{array}{l}\text { Standart } \\
\text { Hata }\end{array}$ & $\mathbf{R}^{2}$ & $\begin{array}{l}\mathbf{t} \\
\text { değeri }\end{array}$ & p \\
\hline \multirow[t]{2}{*}{ 1.Hipotez } & \multirow{2}{*}{$\begin{array}{c}\text { İş Tatmini İle Örgütsel } \\
\text { Bağlılık Arasında } \\
\text { Pozitif Bir İlişki } \\
\text { Vardır. }\end{array}$} & $\begin{array}{l}\text { Örgütsel } \\
\text { Bağlllık- İş } \\
\text { Tatmini } \\
\end{array}$ & \multirow[b]{2}{*}{ Kabul } & 0,701 & 0,029 & 0,491 & 16,98 & 0,001 \\
\hline & & $\begin{array}{l}\text { İş Tatmini- } \\
\text { Örgütsel } \\
\text { Bağlllık }\end{array}$ & & 0,987 & 0,058 & 0,491 & 25,28 & 0,001 \\
\hline 2.Hipotez & $\begin{array}{c}\text { İş Tatmini İle Örgütsel } \\
\text { Destek Arasında } \\
\text { Pozitif Bir İlişki } \\
\text { Vardır. }\end{array}$ & $\begin{array}{l}\text { Örgütsel } \\
\text { Destek- İş } \\
\text { Tatmini }\end{array}$ & Kabul & 0,781 & 0,031 & 0,681 & 16,98 & 0,001 \\
\hline 3.Hipotez & $\begin{array}{c}\text { Örgütsel Destek İle } \\
\text { Örgütsel Bağlılık } \\
\text { Arasındaki İlişki De İş } \\
\text { Tatmininin Etkisi } \\
\text { Vardır. }\end{array}$ & $\begin{array}{l}\text { İş Tatmini- } \\
\text { Örgütsel } \\
\text { Destek }\end{array}$ & Kabul & 0,825 & 0,035 & 0,681 & 25,28 & 0,001 \\
\hline
\end{tabular}

Bu sonuçlar önceki araştırma sonuçlarını da destekler niteliktedir. Öyle ki eğer çalışan işinden memnun değil ise, örgüte olan bağlllığı azalacaktır (Ülbeği ve Yalçın, 2016: 83). Eisenberger vd. (1997: 812-820), algılanan örgütsel destek ve iş tatmini arasında olumlu ve güçlü bir ilişki saptamışlardır. Örgütün çalışanlarını birer değer olarak kabul etmesi, çalışanların örgüt ile olumlu duygusal bağ kurmasına neden olmaktadır. Örgüt değerlerinin çalışanların esenliğini ve mutluluğunu dikkate alması çalışanların iş tatminlerini doğrudan etkilemektedir (Turunç ve Çelik, 2010: 185).

\section{SONUÇLAR VE ÖNERILER}

Algılanan örgütsel destek işletmelerde işveren ve iş gören arasındaki ilişkiyi ortaya koyması açısından önem taşıyan bir kavramdır. Bilindiği üzere örgütsel destek algısı yüksek olan iş görenlerin daha yüksek örgütsel bağlılık davranışı sergiledikleri de bir gerçektir. Bu nedenle öncelikle iş görenlerin örgütsel destek algısını oluşturan faktörlerin neler olduğunu ve bu algının örgütsel bağlılık ile olan ilişkisini ortaya çıkarmak önem taşımaktadır. İşletmelerde çok sayıda araştırmaya konu olan fakat eğitim gibi önemli bir sektör, öğretmenlik gibi önemli bir meslek olan bir alanda yapılan çalışmaların sayısının azlığı araştırmanın öneminin belirlenmesinde etkili olmuştur.

Eğitim alanında liseden üniversiteye kadar işleyen sürecin kalitesi hem kurumlarda uygulanan stratejilerden hem de öğretmenlerin kuruma bağlılığından etkilenmektedir. Devlet kontrolünde olması gereken iki önemli sektörün sağlık ve eğitim olduğu düşünüldügünde eğitim faaliyetlerinin bireysel, toplumsal ve ekonomik gelişme ile ilişkili olduğu ve bu nedenle verimliliğinin ve etkinliğinin arttırılması gerektiği gerçeği yadsınamamaktadır. Özel ve genel liselerde çalışma ortamının, algılanan desteğin ve iş tatmin düzeyinin farklı olacağı görüşünden hareketle bu durumun oluşturacağı farklılığın ortaya konulması ve iyileştirme önerilerinde bulunulması hedeflenmektedir.

Proje kapsamında öğretmenlerin örgütsel desteğe ilişkin algılarının ve örgütsel bağlılıklarının ölçülerek bu algının ve örgüte bağlılıklarının iş tatminlerine etki düzeyini belirlemek amaçlanmıştır. Yapılan analizler sonucu iş tatmini ile örgütsel bağlllık ve örgütsel destek arasında pozitif bir korelasyonun varlığı, örgütsel destek ile örgütsel bağlllık arasındaki ilişkide de iş tatmininin rolü tespit edilmiştir.

Ayrıca öğretmenlerin en fazla iş tatmini sağladıkları alanlar; mesleğin öğrencileri yönlendirmede fırsat ve başkaları için bir şeyler yapabilme hissi vermesi olmuştur. Terfi imkanları ise iş tatmininin azaldığı ifadeler arasında bulunmuştur. Öğretmenlerin mesleğin öğrencileri yönlendirmede fırsat ve başkaları için bir şeyler yapabilme hissi vermesi yönünden örgütsel destek algısı yüksek çıkarken, sağlanan özlük haklarının tatmini açısından örgütsel destek algıları düşük düzeydedir. Öğretmenlerin kendini tamamen çalıştığı okulun bir parçası ve okulda istikrarlı ve gelişmeyi hedefleyen bir yapının olduğunu görmesi örgütsel bağlılık açısından yüksek puan alan maddelerdir. Buna karşılık okul yönetiminin bir parçası olduğu hissi örgütsel bağlllık açısından en az katılımın olduğu ifade olarak tespit edilmiştir. 
A. Diken- N. Koçyiğit - E. Ö. Topaloğlu - A. Yılmaz 11/4 (2019) 2698-2716

$\mathrm{Bu}$ sebeplerle öğretmenlerin motivasyon düzeylerinin ve performanslarının tespiti, değişimi yönetmek, öğretmenlerin görüşlerini dinlemek, ekip ruhunu güçlendirmek yerinde öneriler olacaktır. Çalışma sonuçları tüm paydaşları (üniversite, Milli Eğitim Bakanlığı ve diğer bakanlıklar, kamu, toplum, eğitimciler, STK'lar) çalışmanın ortaya koyacağı metot ve bulgular açısından ilgilendireceğinden araştırmanın kilit bir öneme sahip ve sağlayacağı katma değerin yüksek olduğunu göstermektedir.

Sonraki araştırmalarda diğer eğitim kurumlarında (ilköğretim, özel eğitim kurumları, üniversiteler, gibi) da benzer çalışmalar yapılarak araştırma sonuçları genişletilebilir. Ayrıca algılanan örgütsel desteğin, iş ortamı, performans, işten ayrılma niyeti ve örgütsel vatandaşlık gibi diğer değişkenlerle ilişkileri araştırılabilir.

\section{KAYNAKÇA}

Akgündüz, Y. ve Çakıcı, A. C. (2015). Algılanan örgütsel desteğin örgütsel vatandaşlık davranışlarına etkisinde örgütsel stresin aracılık rolü: beş yıldızlı otel işletmelerinde bir araştırma, Uluslararası Alanya İşletme Fakültesi Dergisi, 7(2).

Allen, J. N. ve Meyer, P. J. (1990). The measurement and antecedents of affective, continuance and normative commitment to the organization, Journal of Psychology, 63 (1-18).

Aşık, A. N. (2010). Çalışanların iş doyumunu etkileyen bireysel ve örgütsel faktörler ile sonuçlarına ilişkin kavramsal bir değerlendirme, Türk İdare Dergisi, 467, 31-51.

Avşaroğlu, S., Deniz, M.E. ve Kahraman, A. (2005).Teknik öğretmenlerde yaşam doyumu iş doyumu ve mesleki tükenmişlik düzeylerinin incelenmesi, Selçuk Üniversitesi Sosyal Bilimler Enstitüsü Dergisi, 14, 116-129.

Aykaç, A. (2010).İş doyumunun örgütsel bağlllığa etkisi, Yüksek Lisans Tezi, Gazi Üniversitesi Sosyal Bilimler Enstitüsü, Ankara.

Bakan, İ. ve Büyükmeşe, T. (2004). Örgütsel iletişim ile iş tatmini unsurları arasındaki ilişkiler: akademik örgütler için bir alan araştırması, Akdeniz İ.I.B.F. Dergisi, 7, 1-30.

Balay, R. (2000).Yönetici ve Öğretmenlerde Örgütsel Bağhllık, Ankara: Nobel Yayın Dağıtım.

Baş, Türker (2006). Anket Nasıl Hazırlanır?, Anket Nasıl Uygulanır?, Anket Nasıl Değerlendirilir?, 4. Baskı, Ankara: Seçkin Yayıncılık.

Başaran, M. (2017). Okul yöneticilerinin yönetim biçimleri ile öğretmenlerin iş doyumu arasındaki ilişkinin incelenmesi, Yüksek Lisans Tezi, Gazi Üniversitesi Ĕ̆itim Bilimleri Enstitüsü, Ankara, 101.

Bayram, L. (2005). Yönetimde yeni bir paradigma: örgütsel bağlllık, Sayıştay Dergisi, 59, 125-139.

Baysal, A. İ., Baysal, G. , Aksu, G. ve Aksu, N. (2014). Presenteeism (işte varolmama sorunu) ile örgütsel bağlllık arasındaki ilişki: Adnan Menderes Üniversitesi akademik personeli üzerinde bir uygulama, Electronic Journal Of Vocational Colleges, Ağustos 2014 Bürokon Özel Sayısı, 134-152.

Biswas, S. ve Bhatnagar, J. (2013). Mediator analysis of employee engagement: role of perceived organizational support, po fit, organizational commitment and job satisfaction, Vikalpa, 38 (1), 27-40.

Chiang, C-F. ve Hsieh, T-S. (2012). The impacts of perceived organizational support and psychological empowerment on job performance: the mediating effects of organizational citizenship behavior, International Journal Of Hospitality Management, 31, 180-190.

De Roover, A. (2015). The influence of talent management on personal growth initiative and the mediating role of perceived organizational support and the moderating role of culture, 1-53.

Dikmen, A. A. (1995). İş doyumu ve yaşam doyumu ilişkisi, Ankara Üniversitesi SBF Dergisi, 50(03).

Durmuş, S. ve Günay, O. (2007).Hemşirelerde iş doyumu ve anksiyete düzeyini etkileyen faktörler, Erciyes Tıp Dergisi, 29 (21), 139-146.

Eisenberger, R., Armeli, S., Rexwinkel, B., Lynch, P.D. ve Rhoades, L. (2001). Reciprocation of perceived organizational support, Journal of Applied Psychology, 86(1), 42-51.

Eisenberger, R., Cummings, J., Armeli, S. ve Lynch, P. (1997). Perceived organizational support, discretionary treatment, and job satisfaction, Journal of Applied Psychology, 82, (5), 812-820.

Eisenberger, R., Huntington, R., Hutchison, S., ve amp; Sowa, D. , (1986). Perceived organizational support, Journal of Applied Psychology, 71, 500-507. 
A. Diken- N. Koçyiğit - E. Ö. Topaloğlu - A. Yılmaz 11/4 (2019) 2698-2716

Eker, G. (2006). Örgütsel adalet algısı boyutları ve iş doyumu üzerine etkileri, Yüksek Lisans Tezi, Dokuz Eylül Üniversitesi Sosyal Bilimler Enstitüsü, İzmir.

Erdem, H. (2014). Algılanan örgütsel destek ve kontrol odağının stresle başa çıkma yöntemleri üzerine etkileri: psikolojik sermayenin bu süreçteki rolü ve bir alan araştırması, Doktora Tezi, İnönü Üniversitesi Sosyal Bilimler Enstitüsü, Malatya.

Eren, E. (1993). Örgütsel davranış ve yönetim psikolojisi, Yenilenmiş V. Baskı, İstanbul: Beta Basım Yayın Dağıtım.

Erkoç, Ç. İ. (2015). Algılanan örgütsel destek ve iş performansı arasındaki ilişkide öz yeterlilik faktörünün düzenleyici rolü: bankacılık sektöründe bir araştırma, Yüksek Lisans Tezi, İstanbul Kültür Üniversitesi Sosyal Bilimler Enstitüsü, İstanbul.

Gürbüz, R. (2012). Algilanan örgütsel destek ve örgütsel güvenin, örgütsel bağlılık ile ilişkisi, Yüksek Lisans Tezi, Atatürk Üniversitesi Sosyal Bilimler Enstitüsü, Erzurum.

İlişen, E. (2017). Öğretmenlerin örgütsel destek algıları ile örgütsel bağlılıkları arasındaki ilişki, Yüksek Lisans Tezi, Eskişehir Osmangazi Üniversitesi Eğitim Bilimleri Enstitüsü, Eskişehir.

Kaplan, M. ve Öğüt, A. (2012). Algılanan örgütsel destek ile örgütsel bağlllık arasındaki ilişkinin analizi: otel işletmelerinde bir uygulama, Süleyman Demirel Üniversitesi İktisadi ve İdari Bilimler Fakültesi Dergisi, 17(1).

Kaya, B. (2012). Algılanan örgütsel destek düzeyinin ve çalışanların kariyer tatmininin işten ayrılma niyeti üzerindeki etkileri: konaklama işletmelerinde bir uygulama, Akdeniz Üniversitesi Sosyal Bilimler Enstitüsü, Antalya.

Kraimer, M. L. ve Wayne, S. J. (2004). An examination of perceived organizational support as a multidimensional construct in the Context of an expatriate assignment, Journal of Management, 30 (2), 209-237.

Kurt, E. (2013). Algılanan sosyal destek ve iş performansı ilişkisinde işe bağlılığın aracı etkisi: turizm işletmelerinde bir araştırma, Yüksek Lisans Tezi, Hacettepe Üniversitesi Sosyal Bilimler Enstitüsü, Ankara.

Levinson, H. (1965). Reciprocation: the relationship between man and organization, Administrative Science Quarterly, 9, 370-390.

Mathieu, J. E. ve Zajac, D. M. (1990). A review and meta-analysis of the antecedents, correlates, and consequences of organizational commitment, Psychological Bulletin, 108, 171-194.

Meyer, J. P. ve Allen, N. J. (2004). TCM employee commitment survey academic users guide, Canada Department of Psychology The University of Western Ontario.

Meyer, J. P. ve Allen, N. J. (1997). Commitment in the workplace: theory, research and application, Sage Publications, United Kingdom.

Oktar, N. M. (2015). Engelli bireylerle çalışanlarda algılanan örgütsel destek ve tükenmişlik düzeyinin iş tatmini üzerindeki etkisi: istanbul ili beykoz ilçesi örneği, Yüksek Lisans Tezi, Yalova Üniversitesi Sosyal Bilimler Enstitüsü, Yalova.

Önderoğlu, S. (2010). Örgütsel adalet algısı, iş aile çatışması ve algılanan örgütsel destek arasındaki bağlantılar, Yayımlanmamış Yüksek Lisans Tezi, Ankara Üniversitesi Sosyal Bilimler Enstitüsü, Ankara.

Özdevecioğlu, M. (2003). Algılanan örgütsel destek ile örgütsel bağlllık arasındaki ilişkilerin belirlenmesine yönelik bir araştırma, Dokuz Eylül Üniversitesi İ.̇.B.F. Dergisi, 18, (2).

Özer, M. ve Bakır, B. (2003). Sağlık personelinin motivasyonuyla ilgili etmenlerin belirlenmesi, Gülhane Tıp Dergisi, 45 (2), 117-122.

Özkalp, E. ve Kırel, Ç. (2004). Örgütsel davranış, 2. Baskı, Eskişehir: Anadolu Üniversitesi Yayınları.

Öztürk, M. ve Şahbudak, E. (2016). Akademisyenlikte iş doyumu, Uluslararası Sosyal Araştırmalar Dergisi, 8, (40) 594-501.

Randall, D. M. (1987). Commitment and the organization: the organization man revisited, Academy of Management Review, 12 (3), 460-471.

Rhoades, L. ve Eisenberger, R. (2002). Perceived organizational support: a review of the literature, Journal of Applied Psychology, 87 (4), 698-714.

Rhoades, L., Eisenberger, R. ve Armeli, S. (2001). Affective commitment to the organization: the contribution of perceived organizational support, Journal of Applied Psychology, 86 (5), 825-836. 
A. Diken- N. Koçyiğit - E. Ö. Topaloğlu - A. Yılmaz 11/4 (2019) 2698-2716

Samadov, S. (2006). İş doyumu ve örgütsel bağlılık: özel sektörde bir uygulama, Yüksek Lisans Tezi, Dokuz Eylül Üniversitesi Sosyal Bilimler Enstitüsü, İzmir.

Semerci, A. S. (2005). İş motivasyonu ve sonuçları: Türkiye Cumhuriyet Merkez Bankası'nda bir uygulama, Uzman Yeterlilik Tezi, Türkiye Cumhuriyet Merkez Bankası İnsan Kaynakları Genel Müdürlüğ̈̈, Ankara.

Sezgin, B. O. (2015). Algılanan örgütsel destek ile iç girişimci davranışı ilişkisinde örgütsel güvenin rolü, Doktora Tezi, Dokuz Eylül Üniversitesi Sosyal Bilimler Enstitüsü, İzmir.

Sığrı, Ü. ve Basım, N. (2006). İş görenlerin iş doyumu ile örgütsel bağlllık düzeylerinin analizi: kamu ve özel sektörde karşılaştırmalı bir araştırma, SÜ İ̈BF Sosyal ve Ekonomik Araştırmalar Dergisi, 6 (12), 130-155.

Spector, P.E. (1997). Job satisfaction: application, assessment, causes, and consequences, Sage Publications, United Kingdom.

Steers, R. M., M., Richard T. Ve Shapiro, D. L. (2004). The future of work motivation theory, Academy of Management Review, 29, (3), 379-387.

Sürücü, L. ve Maşlakçı, A. (2018). Örgütsel bağlılık üzerine kavramsal inceleme, International Journal Of Management and Administration, 2 (3), 49-65.

Süzerler, N. S. (2013). Öğretmenlerde algılanan örgütsel destek ile eğitim denetmenlerine yönelik tutum arasındaki ilişki, Yüksek Lisans Tezi, Hasan Kalyoncu Üniversitesi Sosyal Bilimler Enstitüsü, Gaziantep, $81-82$.

Taşkın F. (2010). Örgütsel güven ve örgütsel bağlılık üzerine bir alan araştırması, Organizasyon ve Yönetim Bilimleri Dergisi, 2, (1).

Türk Dil Kurumu, (2018).tatmin, https://sozluk.gov.tr/?kelime=tatmin\%20olmak, Erişim Tarihi, 22 Mart 2018.

Türk Dil Kurumu, (2014). bağlllık, http://www.tdk.gov.tr/index.php?option=com_gts\&kelime=Doyum,ErişimTarihi , 30 Temmuz 2018.

Telef, B. (2011). Öğretmenlerin öz yeterlikleri, iş doyumları, yaşam doyumları ve tükenmişliklerin incelenmesi, Elementary Education Online, 10 (1), 91-108.

Turunç, Ö. ve Çelik, M. (2010). Çalışanların algıladıkları örgütsel destek ve iş stresinin örgütsel özdeşleşme ve iş performansına etkisi, Yönetim ve Ekonomi Dergisi, 17 (2), 184-206.

Ulutaş, S. (2015). Algılanan şirket desteğini etkileyen faktörler ve algılanan şirket desteği ile çalışan bağlılığı arası ilişki, Yüksek Lisans Tezi, İstanbul Teknik Üniversitesi Sosyal Bilimler Enstitüsü, İstanbul.

Ülbeği, İ. ve Yalçın, A. (2016). Örgütsel bağlllık ve iş doyumu ilişkisinin meta analiz yöntemiyle incelenmesi, Türk Psikoloji Dergisi, 31 (77), 80-98.

Üren, S. G. ve Çorbacioğlu, S. (2012). Algılanan örgütsel desteğin örgütsel bağlllı̆̆a etkisi: imalat sektöründe faaliyet gösteren bir işletme örneği. İktisadi ve İdari Bilimler Fakültesi Dergisi, 14(1), 1-24.

Üstüner, M. (2009). Öğretmenler için örgütsel bağlılık ölçeği: geçerlik ve güvenirlik çalışması, İnönü Üniversitesi Ĕ̆itim Fakültesi Dergisi, 10 (1), 1-17.

Yelboğa, A. (2007). Bireysel demografik değişkenlerin iş doyumu ile ilişkisinin finans sektöründe incelenmesi, Sosyal Bilimler Dergisi, 4 (2), 1-18. 